\title{
Reassessing Export Diversification Strategies: A Cross-Country Comparison
}

\author{
Raul Gouvea, Gautam Vora \\ Department of FIT Management, Anderson School of Management, University of New Mexico, Albuquerque, \\ NM, USA \\ Email: rauldg@unm.edu, vora@unm.edu
}

Received 5 January 2015; accepted 20 January 2015; published 23 January 2015

Copyright @ 2015 by authors and Scientific Research Publishing Inc.

This work is licensed under the Creative Commons Attribution International License (CC BY). http://creativecommons.org/licenses/by/4.0/

(c) (i) Open Access

\section{Abstract}

This article uses a sample of 44 countries to assess their export performance over the period 1988-2012, using the single-index model, a part of the modern portfolio theory. The article builds four clusters of countries classified by the dominance of exports of 1) fuel products, 2) manufactured products, 3) food items and agricultural products and 4) ores and minerals. All countries in the sample obtain a dominant majority of their export earnings from these broad categories of products. The results are that the export portfolios comprised of manufactured products have a superior performance than export portfolios comprised of non-manufactured products. In particular, from a risk-return perspective the export portfolio of manufactured products dominates the export portfolio of food items and agricultural products which in turn dominates the export portfolio of fuel products and of ores and minerals. This domination validates $a$ priori belief that manufacturing goods and exports is the best strategy for development of exports of a country. An important caveat is that this rosy scenario is unlikely to last. The implications for countries and firms are also discussed.

\section{Keywords}

Qualitative/Quantitative Comparisons, International Trade Theory, Economic Clustering, Single Index Model, Export Portfolio Performance

\section{Introduction}

In this article, we investigate an economic phenomenon and a policy conundrum which have increased in importance as time has gone by. The world is no longer divided in two groups, such as developed countries and underdeveloped countries. As more and more countries have thrown away the yoke of colonialism as well as socialism/communism, they have increasingly recognized the important role international trade can play in eco- 
nomic development (for those countries which are on the lower rungs of economic development ladder) to pull the poor population out of poverty and more economic development (for those countries which are on the higher rungs of economic development ladder) to create more employment as well-paying jobs become the rallying cry of politicians and policy-makers. More countries continue to join the global economy via international trade institutions (General Agreement on Tariffs and Trade (GATT), World Trade Organization (WTO) and numerous regional free-trade blocs) and international financial institutions (International Monetary Fund (IMF), International Bank for Reconstruction and Development (IBRD or World Bank) and numerous regional development banks). It is customary for governments to pay close attention to international trade for the sake of prosperity of the country. The governments have realized that the benefits of international trade outweigh its costs. The benefits are tangible in terms of improvement in socio-development factors such as sanitation, health, longevity, skills, education, manufacturing technology, environment protection, pollution control, bio-diversity and the like as well as in economic-development factors such as export earnings, growth in GDP and growth in per capital income, improvement in income and wealth inequality and the like.

The economic phenomenon and policy conundrum are how a country approaches exports and export-promotion policies. The question is whether exports achieved by different countries have improved in their characteristics of earnings and volatility. This question is of fundamental importance in economic development literature because it would shed light on export-trade practices of countries at various levels of development. The question can be put in other words: Do export portfolios comprised of manufactured products have a superior performance than export portfolios of non-manufactured products? The same question is of fundamental importance in international business management literature because it would shed light on decisions about export promotion zones (EPZs) or special economic zones (SEZs), the scope, scale and modalities of participation in EPZs and SEZs, regulatory and compliance structure, financial and supply-chain intermediation and the like ${ }^{1}$. This question is of fundamental importance in political science, public finance and public policy literature because it would shed light on numerous subsidies and tax structures and their efficacy, the issues of public-private partnership, the use of eminent-domain (i.e., public use) statute and compensation thereunder, a country's internal political set-up and division of political power, and the like.

On the one hand, one can claim that the question is straightforward while the answers are intuitively obvious. On the other hand, one must recognize that the answers are neither intuitive nor obvious until demonstrated and perhaps explained. In this article, we are interested more in demonstrating whether export portfolios of manufactured products have better risk-return trade off than those of non-manufactured products. In the interest of space, we provide in this article only a brief explanation of the phenomenon; a detailed explanation is the subject of another article.

Our results demonstrate that export portfolios of manufactured products indeed have better risk-return tradeoff than those of 1) fuel products, 2) ores and minerals and 3) food items and agricultural products. We observe that export portfolios of manufactured products have more stability (i.e., lower volatility) and relatively higher returns than those of other three categories. The economies (i.e., countries) which rely on exports of fossil fuel products, extractive industrial products or agricultural products (typically classified as natural-resourcebased products) tend to have poorer risk-return tradeoff; these portfolios exhibit higher volatility and relatively lower returns over the sample period.

The contribution of the article is in two sets of literatures, viz., economics, more particularly, international trade, and international business. The main contribution is the demonstration that countries with exports dominated by manufactured products are rewarded with stable earnings from their exports. These export earnings are expected to bring about socio-economic development to their countries at a higher level or a faster pace or is expected to be broadly distributed in the populace. This conclusion has implications for economic policy of the governments for economic development, industrialization, export-promotion, establishment of EPZs or SEZs, incentives for businesses to locate their operations in these zones, subsidies of various kinds, infrastructure development, concentration of development clusters, education (e.g., languages, academic disciplines of science, technology, engineering and mathematics (STEM disciplines)), ancillary development of complementary industries, such as tourism, business processes, information technology, telecommunication, financial institutions, R\&D-oriented institutions, and many other variables necessary for a well-functioning modern economy. Likewise this conclusion has implications for business firms' policies for business development projects, managerial skills and development thereof, hiring and training practices, raising the necessary capital domestically or over-

\footnotetext{
${ }^{1}[1]$ provides an interesting study of global value chains.
} 
seas, in-sourcing or outsourcing business processes, cultural sensitivity and national proclivities, and supplementary practices such as labor relations and compliance with various regulatory requirements.

This article is organized as follows. Section 2 provides a brief literature review. Our goal is to point out the trajectory of economic thought on gains from export-led growth rather than provide a detailed bibliography of the subject area. Section 3 provides a discussion of data, methods, hypotheses and expectations of results. Section 4 provides results and a discussion thereof. Section 5 provides caveats as well as implications for future research and government and business policies. Section 6 concludes the article.

\section{Literature Review}

Since the mercantilism years, economists have praised the economic and social benefits of international trade ([2]-[6]). Among the classical economists, for instance, Adam Smith [7] recognized the gains from trade even though his conception of surplus value is suspect. Ricardo [8] refined the concept of gains from trade into a theory of comparative advantage. It was only a matter of time for the idea and importance of international trade to become part of mainstream economics.

More recently, in the 1950s and 1960s, countries started paying more attention to export-led growth strategies; they emphasized strategies to diversify their export portfolio among which the most important was the addition of manufactured goods to their portfolio of natural-resource-based goods ([9]-[14]). The deterioration of the terms of trade of commodities vis-à-vis those of manufactured products fostered the adoption of an export-led growth strategy ([15]-[20]). From another perspective, it has also been noted that commodity prices are characterized by 30 - 40-year-long super-cycles ([21]-[22]). In the post-ware era, many countries became modern-day mercantilists having adopted export-promotion policies and protectionist measures for their various agricultural and industrial sectors. These measures, however, increased the volatility of exports thereby further penalizing countries specializing in exports of natural resource-based-goods ${ }^{2}$. Consequently, the belief that the addition of manufactured products to their export structure would help to alleviate export earnings fluctuations has become an article of faith ([6] [24]-[29]).

On the other hand, export-led growth strategies have the potential to ease pressures on a country's balance of payments, induce foreign direct investment, gain economies of scale, bring skills in development, result in a more efficient allocation of resources within an economy and thereby collectively culminate in efficiencies all around ([30]-[33]). In addition, the inter-industry impacts of export-led growth strategies and their spill-over effects on upstream and downstream (forward and backward) linkages improve the infrastructural foundations of a productive economy ([34]-[36]).

In addition to issues related to a country's domestic effects from the implementation of an export-led growth strategy ([37]-[39]), the adoption of more diversified export structure is rationalized on the basis of export concentration and export earnings instability ([9] [18] [40]-[45]) $)^{3}$. A conventional wisdom has taken hold that a country's concentration on the exports of a few natural-resource-based goods has been a major source of export earnings instability. Alternatively stated, the more concentrated a country's exports, the lower the probability that export earnings fluctuations in some of its products could be offset by counter-fluctuations in others ([6] [11] [48]-[52]).

The conventional wisdom on export diversification states that if earnings from various categories of exports are not highly correlated with one another then the country's portfolio of exports is likely to have to lower earnings volatility (i.e., instability or fluctuations). The export diversification strategy is usually equated to the addition of manufactured products to a country's export portfolio on the assumption that export earnings from manufactured products are less correlated than those between pairs of commodities of natural-resource-based products ([53]-[58]). A corollary of this suggestion is that a singular specialization in primary products or manufactured products per se may not result in higher or lower level of fluctuations in export earnings, respectively.

[58] [59] point out that export earnings instability is likely related to the positive correlation of proceeds from exports of primary products and the tendency of these primary products to possess high price instability ([48] [60] [61]). Similarly, exporters of manufactured products may face the same type of earnings instability as exporters of primary products do. Thus, an assessment of export strategies should not only address the concentration and structure of exports, but also the composition of export portfolios.

${ }^{2}$ [23] provides insights on nontraditional export promotion programs.

${ }^{3}$ See [46] and [47] for a review of the theoretical and empirical literature on this topic. 
Exports as a tool of economic growth and international trade as a theory have a long and distinguished history in economic thought ${ }^{4}$. This explains the trajectory of the literature review from the old to the new. In addition it explains the move from pure theoretical aspects to a practical analysis of exports.

In this article we explore the impact of a country's composition of exports of products on its export earnings instability. Using the single index model, we examine the oft-repeated conjecture that countries whose exports are dominated by manufactured products will have a superior performance than countries whose exports are dominated by fuel products (petroleum and related products), food items and agricultural products (agricultural produce and related products from agricultural industries), and ore and mineral products (extractive industries).

The manufactured products are generally considered to have the most value added and are the "dream" exports of a country wishing to move up or stay at the highest rungs of development. The modern life runs on various forms of energy among which petroleum-based fuel products are the largest and most important. The prices and variability of the prices of these fuel products cause ripples throughout the global economy as all three, viz., manufacturing, agriculture and extraction, need energy for their own activities. Agricultural products continue to be important for almost all developing countries and for some highly efficient producers among developed countries. These products are the base from which a country would wish to develop more as subsistence economy gives way to agricultural economy to industrial economy to service or knowledge economy. Extractive industries likewise provide a base from which a country would wish to develop further. Both agricultural and extractive industries provide "commodities" which are essential for all other product-manufacturing but which provide an exceedingly limited price-setting power to the producer. Further up the chain of development, we must recognize that the commoditization is about not only where proprietary products become generic but also where technological prowess necessary for producing the said products becomes commonplace. Consequently, not only agricultural products and extractive products are commodities in the original sense of the word, but also some of the new-fangled products such as memory chips do become commodities as the quantum of value-added is perceived to decline to a negligible level.

An examination of global trade in these broad grouping can give us insight into many facets of global economy. In this article we concentrate only on the analysis of performance of countries whose exports are dominated by one of broad categories of products.

\section{Data, Methods, Hypotheses and Expected Results}

This section describes the empirical examination process employed in this study. The themes from literature inform us about the method we can use to evaluate the performance of exports; modern finance comes readily to mind. This method should help us evaluate the returns on exports in light of instability (fluctuations) of exports; modern finance has developed measures of fluctuations as well as risk-return tradeoff ratios. Naturally, these methods require data on international exports. Therefore, this section gives details of data, empirical methods, hypotheses on world-trade-based fluctuations and performance ratios. The section concludes by detailing expected results.

\subsection{Data}

Our sample consists of 44 countries for the period from 1988 to 2012. The countries on the sample relied for the large majority of their total exports earnings on one of the four major categories, viz., 1) fuel products such as oil and natural gas, 2) manufactured products, 3) food items and agricultural produce and products and 4) ores and minerals (extractive products). Thus, the grouping serves as a proxy for the export specialization of their countries.

1) Fuel Products: This group includes 13 exporters of petroleum and natural gas products. The exports include variation of natural gas such as LNG for Angola and crude for Norway. The countries are Angola, Bolivia, Brunei, Iran, Iraq, Kuwait, Nigeria, Norway, Qatar; Russia ${ }^{5}$; Saudi Arabia, Venezuela and UAE.

2) Manufactured Products: This group includes 16 exporters of manufactured products. The exports range

\footnotetext{
${ }^{4}$ The international trade theorists have been the recipient of the Nobel Memorial Prize in Economic Sciences (officially the Sveriges Riksbank Prize in Economic Sciences in Memory of Alfred Nobel) practically since its founding in 1969: Gunnar Myrdal in 1974; Bertil Ohlin and James E. Meade in 1977; Robert A. Mundell in 1999 and Paul Krugman in 2008. See

http://www.nobelprize.org/nobel_prizes/economic-sciences/laureates/. These prizes may be relatively old but they are assuredly not dated. The issues have remained the same as [62] points out in an interesting study of the nineteenth and twentieth centuries.

${ }^{5}$ Russia's data start from 1992Q1 for quarterly data and therefore from 1992 for annual data.
} 
from planes and helicopters for France and the USA, electronic equipment and vehicles for South Korea, computer software and garments for India, steel for Turkey, machinery and equipment for Poland and vehicles for Germany. The countries are China, France, Germany, India, Japan, Malaysia, Mexico, Poland, Portugal, Singapore, South Korea, Thailand, Turkey, the UK, the USA and Vietnam.

3) Food Items and Agricultural Products: This group includes six exporters of food items and agricultural products. The exports include tropical and non-tropical agricultural products, ranging from soybeans and derivatives for Argentina, to Uganda's coffee and tea, and Malawi's raw tobacco. The countries are Argentina, Côte d'Ivoire, Malawi, New Zealand, Uganda and Uruguay.

4) Ores and Minerals: This group includes nine exporters of gold such as Guyana and Mali, copper such as Peru, Zambia and Chile, and aluminum ore and niobium such as Sierra Leone. The countries are Chile, Congo, Guyana, Mali, Mauritania, Peru, Sierra Leone, Suriname and Zambia.

Data are collected in nominal US dollars from the Direction of Trade Statistics published by International Monetary Fund. Data are collected for total global exports of each of the aforementioned country and the world as a whole. The last one serves as the broad market of global trade. The data are available in annual and quarterly periodicity. Percentage changes are calculated from these numbers; analogous to stock market these percentage changes may be called export returns. These export returns are used in the empirical methods described below.

\subsection{Methods}

Diversification of risk in the portfolio context emerged out of the field of finance in the 1950s, particularly attributed to the work of Markowitz ([63] [64]). Markowitz provided statistical foundation and a method for effectively reducing investment risk given the fluctuations, the evolution of the gains on risky assets and the pairwise strength of relationships of these assets' returns. The diversification theory asserts that by systematically selecting a group of investment assets an investor could effectively lower the risk in the portfolio compared with the risk borne by any individual asset. Sharpe [65] and Lintner [66] provided the necessary economic structure and equilibrium arguments to subsume Markowitz's mean-variance criterion to develop a simple mathematical equation for asset-pricing, which was labelled the Capital Asset Pricing Model (CAPM) ${ }^{6}$. These elements became known as the Modern Portfolio Theory. The pricing model gives us the risk-return tradeoff so as to evaluate whether a risky asset would provide a rate of return commensurate with risk borne. This risk-return tradeoff of a risky asset is typically measured against that of the market as a whole, where the market is proxied by a broadbased index of risky assets. Traditionally risk has been measured in one of two ways. In the Markowitz scheme, it is the total risk, measured by the standard deviation. In the Sharpe-Lintner scheme, it is the market-based risk, measured by the beta, which is the average sensitivity of a risky asset to the fluctuations in the market as a whole. This average sensitivity is most often called the systematic risk and the difference between it and the total risk is called the unsystematic risk or unique risk. This unsystematic risk is sought to be reduced by the proper construction of a portfolio. It is not possible to reduce the market-based (i.e., systematic) risk, unless one uses other risk-management instruments and method. In the context of global trade, a country tried to achieve the same objective through export diversification. Whereas the CAPM, as an expectations model, has an important role in many contexts, the investments-related applications have made a heavier use of the empirical counterpart of the CAPM, called the single index model (SIM) ${ }^{7}$.

The "standard" applications of both of these are in the field of investments. Agriculture economists have pioneered their applications in agricultural economics to study crop portfolios of geographic regions and crop portfolios for risk-management practices ([67]-[71]). International trade economists have applied these methods for their empirical work mentioned in literature review ${ }^{8}$. As these pioneers did, we recognize that while CAPM is an

\footnotetext{
${ }^{6}$ The equation of CAPM is given as $E\left(R_{i}\right)=R_{f}+\left\{E\left(R_{m}\right)-R_{f}\right\} \beta_{i}$, where $E\left(R_{i}\right)$ is the expected return on asset $i$ for the next period, $R_{f}$ is the risk-free rate, $E\left(R_{m}\right)$ is the expected return on the market portfolio and $\beta_{i}$ is the average sensitivity of asset $i$ 's returns to those of the market portfolio.

${ }^{7}$ The equation is given as $R_{i, t}=\alpha_{i}+\beta_{i} R_{m, t}+\varepsilon_{i, t}$, where in the current context, $R_{i, t}$ is the return for country or portfolio $i$ for period $t$, $R_{m, t}$ is the return for the index $m$ for period $t, \alpha_{i}$ is the intercept for country or portfolio $i, \beta_{i}$ is the slope coefficient for country or portfolio $i$, and $\varepsilon_{i, t}$ is the error term for country or portfolio $i$ for period $t$.

${ }^{8}$ [72] uses the single index model to construct optimal portfolios to analyze regional free-trade agreements whereas [73] uses the portfolio approach to analyze the risk of international trade.
} 
asset-pricing tool (as its name suggests), SIM is variously used for portfolio construction, performance evaluation, rebalancing, comparison, construction of indexes, benchmarking, etc. We use SIM in a direct way to analyze the performance of export portfolios.

We wish to assess the sensitivity of exports to the fluctuations in global trade. The slope coefficient of the simple linear regression equation captures the sensitivity. In the context of investment theory, as mentioned before, this slope coefficient is called the beta and the regression equation is called the single index model. The estimation of the equation of the SIM is based on an index which serves as the benchmark. In this application, the benchmark is the total world exports. That a country's or a portfolio's exports would fluctuate with total world exports (trade) does not need explanation. The estimation is based on the annual arithmetic "returns" calculated from the total exports for a country, portfolio or the world.

Sharpe ([74]-[76]) introduced one of the more popular reward-to-risk ratios, viz., the reward-to-variability ratio, more commonly called the Sharpe (performance) measure or the Sharpe ratio. The Sharpe ratio is defined as the ratio of the excess return and the standard deviation of that return ${ }^{9}$. Treynor [77] provided another popular reward-to-risk ratio, viz., the reward-to-volatility ratio, more commonly called the Treynor (performance) measure or the Treynor ratio. The Treynor ratio is defined as the ratio of the excess return and the systematic risk of that return ${ }^{10}$. Typically, these ratios are calculated from the ex post data. Ex post ratios are mostly used for performance evaluation whereas ex ante ratios are often used for investment decision-making.

We will need to make a slight modification while applying investment-theoretic performance measures to evaluate countries' export performance; we will use the ex post export return in place of excess export return for a country or its portfolio. This is equivalent to assuming that the risk-free rate is zero. Thus, we use close variants of the Sharpe ratio ${ }^{11}$ and the Treynor ratio ${ }^{12}$, which we will continue to refer as reward-to-risk ratios.

\subsection{Hypotheses}

The purpose of the paper is to evaluate the performance of export portfolios comprising of countries whose exports are dominated by 1) fuel products, 2) manufactured products, 3) food items and agricultural products and 4) ores and minerals. The countries serve the role of assets and returns on exports of the countries serve as asset returns. Given these methodological necessity, the hypothesis can be stated:

1) $\beta_{\text {Fuel }}=\beta_{\mathrm{Mfg}}=\beta_{\mathrm{Ag}}=\beta_{\text {Ores }}$ where $\beta_{\text {Fuel }}, \beta_{\mathrm{Mfg}}, \beta_{\mathrm{Ag}}$, and $\beta_{\text {Ores }}$ are the slope coefficient (beta or average sensitivity to market) for export portfolio for fuel-products-oriented countries, manufactured products-oriented countries, agricultural products-oriented countries and ores and minerals-oriented countries, respectively.

2) $T_{\text {Fuel }}=T_{\mathrm{Mfg}}=T_{\mathrm{Ag}}=T_{\text {Ores }}$, where $T_{\text {Fuel }}, T_{\mathrm{Mfg}}, T_{\mathrm{Ag}}$, and $T_{\text {Ores }}$ are the Treynor measure for export portfolio for fuel-products-oriented countries, manufactured products-oriented countries, agricultural products-oriented countries and ores and minerals-oriented countries, respectively. The Treynor measure is defined as the ratio of the average return for the sample period and the slope coefficient for the sample period. The Treynor measure gives us an indication of the return earned per unit of risk where risk is defined in terms of the average sensitivity of the portfolio's returns to the aggregate returns.

3) $S_{\text {Fuel }}=S_{\mathrm{Mfg}}=S_{\mathrm{Ag}}=S_{\text {Ores }}$, where $S_{\text {Fuel }}, S_{\mathrm{Mfg}}, S_{\mathrm{Ag}}$, and $S_{\text {Ores }}$ are the Sharpe measure for export portfolio for fuel-products-oriented countries, manufactured products-oriented countries, agricultural products-oriented countries and ores and minerals-oriented countries, respectively. The Sharpe measure is defined as the ratio of the average return for the sample period and the standard deviation for the sample period. The Sharpe meas-

\footnotetext{
${ }^{9}$ Notationally the Sharpe Ratio is $\left(\bar{R}_{i}-\bar{R}_{f}\right) / \sigma_{i}$, where $\bar{R}_{i}$ is the arithmetic average of the returns for country or portfolio $i, \bar{R}_{f}$ is the arithmetic average of the risk-free return and $\sigma_{i}$ is the standard deviation.

${ }^{10}$ Notationally the Treynor Ratio is $\left(\bar{R}_{i}-\bar{R}_{f}\right) / \beta_{i}$, where $\bar{R}_{i}$ is the arithmetic average of the returns for country or portfolio $i, \quad \bar{R}_{f}$ is the arithmetic average of the risk-free return and $\beta_{i}$ is the measure of market-related risk.

${ }^{11}$ In the context of this study, we need not use the risk-free rate. Alternatively, $\bar{R}_{f}$ may be considered equal to zero. Therefore the Sharpe

Ratio becomes $\bar{R}_{i} / \sigma_{i}$ where $\bar{R}_{i}$ is the arithmetic average of the returns for country or portfolio $i$ and $\sigma_{i}$ is the standard deviation of the returns for country or portfolio $i$.

${ }^{12}$ In the context of this study, we need not use the risk-free rate. Alternatively, $\bar{R}_{f}$ may be considered equal to zero. Therefore the Treynor Ratio becomes $\bar{R}_{i} / \beta_{i}$, where $\bar{R}_{i}$ is the arithmetic average of the returns for country or portfolio $i$ and $\beta_{i}$ is the measure of marketrelated risk.
} 
ure gives us an indication of the return earned per unit of risk where risk is defined in terms of the total volatility of the portfolio's returns.

\subsection{Expected Results}

If exports of all the different categories are treated equally in global trade, then we should get the result that all are equally sensitive to the aggregate exports of the world and that risk-return tradeoff is similar for all categories of exports. If, on the other hand, these categories are treated differentially, then we should get the result that their sensitivity to the aggregate exports of the world is different and their risk-return tradeoff is different. If we find evidence of the former, then implications for economic policy, industrial policy and business policies are straightforward; if we find evidence of the latter, then implications will be vastly different. These implications are discussed in a section below.

\section{Results and Discussion}

We evaluate the export performance of the individual 44 countries in the sample from a risk-return perspective. Further we assess the portfolio performance for all four portfolios of countries in the sample. Recall that countries are thought of as assets for a portfolio based on their respective dominant export.

Table 1 gives the single index model estimates for the countries of a portfolio. Three sample periods are reported, viz., the full sample period of 1989-2012 and two ten-year periods of 1989-1998 and 1999-2008. For each period the coefficients of intercept and slope are reported along with their t-statistics below the coefficients. The statistical significances at $10 \%, 5 \%$ and $1 \%$ are indicated by asterisks. Panel A reports the numbers for 13 countries included in the fuel-products-exporting portfolio, Panel B for 16 countries included in the manufactured-products-exporting portfolio, Panel $\mathrm{C}$ for six countries included in the agricultural-products-exporting portfolio, Panel D for nine countries included in the ores-and-minerals-exporting portfolio.

Recall that the slope represents the average sensitivity of export returns to the fluctuations in the index of total world export returns. The sensitivity of the total world exports to itself is by construction 1 . Therefore, the beta (i.e., slope coefficient) higher (lower) than 1 implies higher (lower) volatility of exports.

Countries in the fuel products and ores and minerals export portfolios show much higher degree of systematic risk. On the other hand, countries in the manufactured products and food items and agricultural products show lower levels of risk. Examining the betas for fuel products-exporting countries and ores and minerals-exporting countries we notice a much higher level of exposure to global trade fluctuations than for the food items and agricultural-products and manufactured-products-exporting countries.

The next step is to assess the performance of four export portfolios. Table 2 gives the single index model estimates for each broad export category portfolio for the same three sample periods. On the volatility scale, the five portfolios descendingly are fuel products $(1.7312,1.7304,1.7735)$, ores and minerals $(1.2058,1.3622$, $1.6710)$, food items and agricultural products $(0.9137,1.0029,0.9990)$, manufactured-products $(0.9126,0.9406$, 0.9651) for full sample period, for the first decade of 1989-1998 and for the second decade of 1999-2008. While the risk of export portfolios has fluctuated, the stability of ranking of export portfolios is remarkable. Between the two decades, the decade of 1989-1998 is less risky for fuel products, ores and minerals, manufactured products, and is more risky for food items and agricultural products. Recall that the financial problems started in the USA in mid-2007 and built into a world-wide crisis in 2008 and 2009. Therefore the second ten-year period includes only the beginning of the financial crisis.

Table 3 gives the single index model estimates for each broad export category portfolio for rolling five-year periods. We use quarterly data for this purpose and therefore lose only the first quarter of 1988 to calculate the quarterly rates of return. The full period of 1988-2012 gives us 21 five-year sub-periods. The first five-year period is 1988-1992. We drop the first year and add one at the end, thereby getting the second five-year period of 1989-1993. That is why we call them rolling five-year periods. Table 3 reports these portfolios' coefficients of intercept and slope and their t-statistics.

Figure 1 plots the betas of the four portfolios. Several observations are in order. 1) The risk of fuel products portfolio has remained high throughout the long 25 years even though it has dipped a bit at 2007. 2) The risks of food items and agricultural products portfolio and ores and minerals portfolio seem to be moving in opposite directions. 3) The risk of manufactured-products portfolio has remained the most stable within a narrow range. 4) After 2007 the risks of portfolios of manufactured-products, food items and agricultural products, and ores and 
Table 1. Single index model estimates for the countries of a portfolio. (a) Fuel-products-exporting portfolio; (b) Manufactured-products-exporting portfolio; (c) Food items and agricultural products-exporting portfolio; (d) Ores and minerals-exporting portfolio.

(a)

\begin{tabular}{|c|c|c|c|c|c|c|}
\hline \multirow[b]{2}{*}{ Country } & \multicolumn{2}{|c|}{ Sample Period 1989-2012 } & \multicolumn{2}{|c|}{ Sample Period 1989-1998 } & \multicolumn{2}{|c|}{ Sample Period 1999-2008 } \\
\hline & Intercept & Slope & Intercept & Slope & Intercept & Slope \\
\hline \multirow[t]{2}{*}{ Angola } & 0.0077 & 2.0310 & -0.0720 & 1.7257 & 0.0942 & 2.2661 \\
\hline & 0.1391 & $4.8513^{* * *}$ & -0.9180 & $2.1207^{*}$ & 0.6843 & $2.2634^{*}$ \\
\hline \multirow[t]{2}{*}{ Iraq } & 0.2905 & 0.8673 & 0.7484 & -3.8965 & 0.0144 & 2.7827 \\
\hline & 1.0519 & 0.4135 & 1.0033 & -0.5037 & 0.0579 & 1.5377 \\
\hline \multirow[t]{2}{*}{ Brunei Darussalam } & -0.0006 & 1.3201 & -0.0393 & 1.2644 & 0.1382 & 0.4087 \\
\hline & -0.0111 & $3.2699^{* * *}$ & -0.3096 & 0.9598 & 1.5322 & 0.6232 \\
\hline \multirow[t]{2}{*}{ Nigeria } & -0.0141 & 2.0782 & -0.0220 & 1.4615 & -0.0511 & 2.7157 \\
\hline & -0.2104 & $4.0844^{* * *}$ & -0.1745 & 1.1172 & -0.2860 & $2.0884^{*}$ \\
\hline \multirow[t]{2}{*}{ Qatar } & 0.0726 & 1.5600 & 0.0259 & 1.0131 & 0.0905 & 1.7522 \\
\hline & 1.4752 & $4.1720^{* * *}$ & 0.3892 & 1.4656 & 0.6629 & 1.7656 \\
\hline \multirow[t]{2}{*}{ Kuwait } & 0.2085 & 1.3582 & 0.4446 & 0.6004 & 0.0032 & 2.0442 \\
\hline & 0.7962 & 0.6826 & 0.5997 & 0.0781 & 0.0368 & $3.1931^{* *}$ \\
\hline \multirow[t]{2}{*}{ República Bolivariana de Venezuela } & -0.0239 & 1.7215 & -0.0220 & 1.5966 & -0.0667 & 2.2034 \\
\hline & -0.4838 & $4.5948^{* * *}$ & -0.2266 & 1.5860 & -0.5346 & $2.4282^{* *}$ \\
\hline \multirow[t]{2}{*}{ Saudi Arabia } & -0.0152 & 1.9506 & -0.0855 & 2.2705 & 0.0424 & 1.7229 \\
\hline & -0.3390 & $5.7296^{* * *}$ & -0.9073 & $2.3237^{* *}$ & 0.4140 & $2.3124^{* *}$ \\
\hline \multirow[t]{2}{*}{ Islamic Republic of Iran } & -0.0244 & 1.8002 & -0.0674 & 1.5248 & 0.0907 & 1.4910 \\
\hline & -0.4709 & $4.5754^{* * *}$ & -0.6919 & 1.5092 & 0.7460 & 1.6865 \\
\hline \multirow[t]{2}{*}{ Norway } & -0.0098 & 1.2387 & -0.0535 & 1.7036 & 0.0609 & 0.8576 \\
\hline & -0.4330 & $7.1734^{* * *}$ & -1.1978 & $3.6789^{* * *}$ & 1.3767 & $2.6641^{* *}$ \\
\hline \multirow[t]{2}{*}{ Russian Federation } & 0.0129 & 1.6960 & -0.0049 & 1.8515 & 0.0160 & 1.7334 \\
\hline & 0.3811 & $6.9505^{* * *}$ & -0.0663 & $2.5850^{*}$ & 0.1819 & $2.7016^{* *}$ \\
\hline \multirow[t]{2}{*}{ United Arab Emirates } & 0.0035 & 1.7407 & -0.0041 & 1.1573 & 0.0145 & 1.8939 \\
\hline & 0.1063 & $7.0069^{* * *}$ & -0.0643 & 1.7677 & 0.1956 & $3.5127^{* * *}$ \\
\hline \multirow[t]{2}{*}{ Bolivia } & 0.0111 & 1.4534 & 0.0234 & 1.0724 & -0.0484 & 1.7936 \\
\hline & 0.2597 & $4.4591^{* * *}$ & 0.2528 & 1.1190 & -0.5393 & $2.7463^{* *}$ \\
\hline
\end{tabular}

(b)

\begin{tabular}{|c|c|c|c|c|c|c|}
\hline \multicolumn{7}{|c|}{$\begin{array}{l}\text { Annual returns for } 16 \text { countries in the portfolio. The first row gives the value of the coefficients. The second row gives the } \\
\text { t-stat for the coefficients. The critical values for t-stat for DF }=22 \text { are } 2.8188(1 \%), 2.0739(5 \%) \text { and } 1.7171(10 \%) \text {, and for } \\
\text { DF }=8,3.3554(1 \%), 2.3060(5 \%) \text { and } 1.8595(10 \%) \text {. These are designated by }{ }^{* * *}{ }^{* *} \text { and }{ }^{*} \text { respectively. }\end{array}$} \\
\hline & \multicolumn{2}{|c|}{ Sample Period 1989-2012 } & \multicolumn{2}{|c|}{ Sample Period 1989-1998 } & \multicolumn{2}{|c|}{ Sample Period 1999-2008 } \\
\hline Country & Intercept & Slope & Intercept & Slope & Intercept & Slope \\
\hline \multirow[t]{2}{*}{ China, P.R.: Mainland } & 0.0835 & 1.0834 & 0.0702 & 1.0968 & 0.0998 & 1.1220 \\
\hline & 5.0735 & $8.6714^{* * *}$ & 2.1694 & $3.2668^{* *}$ & 2.6900 & $4.1605^{* * *}$ \\
\hline \multirow[t]{2}{*}{ Japan } & -0.0293 & 0.9635 & -0.0007 & 0.5843 & -0.0528 & 1.1020 \\
\hline & -1.7534 & $7.5925^{* * *}$ & -0.0259 & $2.0705^{*}$ & -1.8165 & $5.2128^{* * *}$ \\
\hline
\end{tabular}




\section{Continued}

\begin{tabular}{|c|c|c|c|c|c|c|}
\hline \multirow[t]{2}{*}{ Republic of Korea } & 0.0132 & 1.0375 & 0.0005 & 1.1949 & -0.0319 & 1.3592 \\
\hline & 0.8737 & $9.0235^{* * *}$ & 0.0175 & $3.8184^{* * *}$ & -1.1152 & $6.5408^{* * *}$ \\
\hline \multirow[t]{2}{*}{ Germany } & -0.0138 & 0.9350 & -0.0366 & 1.3256 & 0.0138 & 0.7873 \\
\hline & -0.8354 & $7.4436^{* * *}$ & -1.2675 & $4.4225^{* * *}$ & 0.3752 & $2.9405^{* * *}$ \\
\hline \multirow[t]{2}{*}{ Turkey } & 0.0414 & 0.9035 & 0.0376 & 0.7254 & 0.0657 & 0.9396 \\
\hline & 2.0637 & $5.9286^{* * *}$ & 1.7014 & $3.1653^{* *}$ & 1.1804 & $2.3230^{* *}$ \\
\hline \multirow[t]{2}{*}{ Mexico } & 0.0787 & 0.6739 & 0.1732 & 0.3566 & 0.0342 & 0.5416 \\
\hline & 2.2936 & $2.5845^{* *}$ & 2.3834 & 0.4732 & 0.7452 & 1.6214 \\
\hline \multirow[t]{2}{*}{ Thailand } & 0.0490 & 0.8629 & 0.0622 & 1.0785 & 0.0034 & 1.0374 \\
\hline & 2.4926 & $5.7823^{* * *}$ & 1.2759 & $2.1328^{*}$ & 0.2405 & $10.1434^{* * *}$ \\
\hline \multirow[t]{2}{*}{ Singapore } & 0.0142 & 1.1216 & 0.0231 & 1.2765 & -0.0420 & 1.4197 \\
\hline & 0.7625 & $7.9116^{* * *}$ & 0.5619 & $2.9940^{* *}$ & -1.3715 & $6.3714^{* * *}$ \\
\hline \multirow[t]{2}{*}{ United States } & 0.0092 & 0.7238 & 0.0445 & 0.4898 & -0.0316 & 0.8590 \\
\hline & 0.8059 & $8.3654^{* * *}$ & 2.9977 & $3.1803^{* *}$ & -1.2441 & $4.6547^{* * *}$ \\
\hline \multirow[t]{2}{*}{ Malaysia } & 0.0304 & 0.9331 & 0.0572 & 1.1271 & 0.0022 & 0.9012 \\
\hline & 1.6635 & $6.7261^{* * * *}$ & 1.6337 & $3.1064^{* *}$ & 0.0717 & $3.9837^{* * *}$ \\
\hline \multirow[t]{2}{*}{ Vietnam } & 0.1593 & 0.9266 & 0.1659 & 1.8116 & 0.1054 & 0.9137 \\
\hline & 2.1682 & 1.6607 & 0.8200 & 0.8635 & 3.6849 & $4.3939^{* * *}$ \\
\hline \multirow[t]{2}{*}{ India } & 0.0569 & 1.0248 & 0.0261 & 1.0558 & 0.0726 & 0.9486 \\
\hline & 3.1906 & $7.5686^{* * *}$ & 1.0698 & $4.1786^{* * *}$ & 2.1516 & $3.8652^{* * *}$ \\
\hline \multirow[t]{2}{*}{ Portugal } & -0.0048 & 0.9857 & -0.0388 & 1.8370 & 0.0192 & 0.6303 \\
\hline & -0.2209 & $5.9266^{* * *}$ & -1.1192 & $5.1053^{* * *}$ & 0.4187 & $1.8913^{*}$ \\
\hline \multirow[t]{2}{*}{ Poland } & 0.0343 & 1.0205 & 0.0240 & 0.8159 & 0.0719 & 1.1092 \\
\hline & 1.3184 & $5.1703^{* * *}$ & 0.4483 & 1.4678 & 1.5108 & $3.2074^{* * *}$ \\
\hline \multirow[t]{2}{*}{ France } & -0.0117 & 0.7842 & -0.0169 & 1.1469 & 0.0055 & 0.5931 \\
\hline & -0.8175 & $7.2099^{* * *}$ & -0.7341 & $4.8016^{* * *}$ & 0.1776 & $2.6528^{* *}$ \\
\hline \multirow[t]{2}{*}{ United Kingdom } & -0.0239 & 0.8765 & -0.0137 & 1.1131 & -0.0178 & 0.6670 \\
\hline & -1.6113 & $7.7816^{* * *}$ & -0.7252 & $5.6961^{* * *}$ & -0.5466 & $2.8094^{* *}$ \\
\hline
\end{tabular}

(c)

Annual returns for six countries in the portfolio. The first row gives the value of the coefficients. The second row gives the $t$-stat for the coefficients. The critical values for t-stat for DF = 22 are $2.8188(1 \%), 2.0739$ (5\%) and $1.7171(10 \%)$, and for $\mathrm{DF}=8,3.3554$ (1\%), 2.3060 (5\%) and 1.8595 (10\%). These are designated by ${ }^{* * * *},{ }^{* * *}$ and ${ }^{*}$ respectively.

\begin{tabular}{ccccccc}
\hline & \multicolumn{2}{c}{ Sample Period 1989-2012 } & \multicolumn{2}{c}{ Sample Period 1989-1998 } & \multicolumn{2}{c}{ Sample Period 1999-2008 } \\
\hline Country & Intercept & Slope & Intercept & Slope & Intercept & Slope \\
\hline Malawi & 0.0608 & 0.0308 & -0.0043 & 0.9425 & 0.0588 & 0.0034 \\
& 1.3757 & 0.0917 & -0.0443 & 0.9409 & 0.6126 & 0.0049 \\
\hline
\end{tabular}




\section{Continued}

\begin{tabular}{ccccccc}
\hline Uruguay & 0.0155 & 0.8779 & 0.0349 & 0.4851 & -0.1030 & 1.7912 \\
& 0.5591 & $4.1592^{* * *}$ & 1.0962 & 1.4711 & -1.3899 & $3.3237^{* *}$ \\
New Zealand & -0.0075 & 0.8730 & -0.0337 & 0.9055 & 0.0355 & 0.5901 \\
& -0.4077 & $6.2405^{* * *}$ & -0.8981 & $2.3237^{* *}$ & 0.9243 & $2.1112^{*}$ \\
Uganda & -0.0208 & 1.6470 & -0.2153 & 4.7411 & 0.0464 & 0.9767 \\
Côte d'Ivoire & -0.2086 & $2.1740^{* *}$ & -0.8391 & 1.7819 & 0.6428 & $1.8614^{*}$ \\
& 0.0401 & 0.3054 & 0.0044 & 0.8508 & 0.0273 & 0.4829 \\
Argentina & 1.1244 & 1.1282 & 0.0573 & 1.0741 & 0.3427 & 0.8341 \\
& 0.0123 & 1.0544 & 0.0293 & 1.2261 & -0.0338 & 1.2168 \\
& 0.5950 & $6.6988^{* * *}$ & 0.7519 & $3.0337^{* *}$ & -0.6838 & $3.3833^{* * * *}$ \\
\hline
\end{tabular}

(d)

\begin{tabular}{|c|c|c|c|c|c|c|}
\hline \multicolumn{7}{|c|}{$\begin{array}{l}\text { Annual returns for nine countries in the portfolio. The first row gives the value of the coefficients. The second row gives } \\
\text { the t-stat for the coefficients. The critical values for t-stat for DF }=22 \text { are } 2.8188(1 \%), 2.0739(5 \%) \text { and } 1.7171(10 \%) \text {, } \\
\text { and for DF = 8, } 3.3554(1 \%), 2.3060(5 \%) \text { and } 1.8595(10 \%) \text {. These are designated by }{ }^{* * *},{ }^{* *} \text { and }{ }^{*} \text { respectively. }\end{array}$} \\
\hline \multirow[b]{2}{*}{ Country } & \multicolumn{2}{|c|}{ Sample Period 1989-2012 } & \multicolumn{2}{|c|}{ Sample Period 1989-1998 } & \multicolumn{2}{|c|}{ Sample Period 1999-2008 } \\
\hline & Intercept & Slope & Intercept & Slope & Intercept & Slope \\
\hline \multirow[t]{2}{*}{ Zambia } & 0.0357 & 1.2039 & 0.1293 & -0.9241 & -0.0414 & 2.4129 \\
\hline & 0.3545 & 1.5723 & 0.7058 & -0.4865 & -0.1744 & 1.3961 \\
\hline \multirow[t]{2}{*}{ Suriname } & 0.0801 & 0.7640 & 0.4587 & -4.1117 & -0.2128 & 2.6130 \\
\hline & 0.5532 & 0.6945 & 1.3354 & -1.1541 & -1.5409 & $2.6022^{* *}$ \\
\hline \multirow[t]{2}{*}{ Democratic Republic of Congo } & -0.0327 & 1.6314 & -0.1217 & 1.9019 & 0.0785 & 0.6670 \\
\hline & -0.4662 & $3.0651^{* * *}$ & -1.3392 & $2.0178^{*}$ & 0.4296 & 0.5020 \\
\hline \multirow[t]{2}{*}{ Chile } & 0.0065 & 1.2817 & -0.0424 & 1.9228 & -0.0475 & 1.7696 \\
\hline & 0.2112 & $5.4956^{* * *}$ & -1.3236 & $5.7826^{* * *}$ & -0.5166 & $2.6486^{* *}$ \\
\hline \multirow[t]{2}{*}{ Peru } & 0.0299 & 1.1447 & -0.0079 & 1.3388 & 0.0304 & 1.3915 \\
\hline & 1.0125 & $5.0995^{* * *}$ & -0.1314 & $2.1556^{*}$ & 0.4821 & $3.0349^{* *}$ \\
\hline \multirow[t]{2}{*}{ Mali } & -0.0408 & 1.6273 & 0.0118 & 0.9654 & -0.2678 & 2.4757 \\
\hline & -0.5404 & $2.8373^{* * *}$ & 0.1280 & 1.0066 & -1.4806 & $1.8821^{*}$ \\
\hline \multirow[t]{2}{*}{ Mauritania } & -0.0375 & 1.4615 & -0.0801 & 1.2103 & 0.0024 & 1.4977 \\
\hline & -1.0831 & $5.5595^{* * *}$ & -1.4849 & $2.1628^{*}$ & 0.0286 & $2.4748^{* *}$ \\
\hline \multirow[t]{2}{*}{ Guyana } & 0.0615 & 0.3372 & 0.1394 & -0.3349 & -0.0506 & 0.8665 \\
\hline & 1.8897 & 1.3648 & 1.9935 & -0.4620 & -1.0319 & $2.4297^{* *}$ \\
\hline \multirow[t]{2}{*}{ Sierra Leone } & 0.5214 & 4.0710 & -0.1736 & 0.2377 & 1.4127 & 5.4991 \\
\hline & 0.4847 & 0.4982 & -0.9824 & 0.1297 & 0.3640 & 0.1949 \\
\hline
\end{tabular}


Table 2. Single index model estimates for four export portfolios.

\begin{tabular}{|c|c|c|c|c|c|c|}
\hline \multicolumn{7}{|c|}{$\begin{array}{l}\text { Annual returns for four export portfolios. The first row gives the value of the coefficients. The second row gives the t-stat } \\
\text { for the coefficients. The critical values for t-stat for DF }=22 \text { are } 2.8188(1 \%), 2.0739(5 \%) \text { and } 1.7171(10 \%) \text {, and for } \\
\qquad \mathrm{DF}=8,3.3554(1 \%), 2.3060(5 \%) \text { and } 1.8595(10 \%) \text {. These are designated by }{ }^{* * * * * *} \text { and }{ }^{*} \text { respectively. }\end{array}$} \\
\hline & \multicolumn{2}{|c|}{ Sample period 1989-2012 } & \multicolumn{2}{|c|}{ Sample period 1989-1998 } & \multicolumn{2}{|c|}{ Sample period 1999-2008 } \\
\hline Export portfolio & Intercept & Slope & Intercept & Slope & Intercept & Slope \\
\hline \multirow[t]{2}{*}{ Fuel products } & 0.0002 & 1.7312 & -0.0269 & 1.7304 & 0.0167 & 1.7735 \\
\hline & 0.0048 & $7.2472^{* * *}$ & -0.4013 & $2.4843^{* *}$ & 0.2253 & $3.2977^{* *}$ \\
\hline \multirow[t]{2}{*}{ Manufactured products } & 0.0054 & 0.9126 & 0.0073 & 0.9406 & -0.0062 & 0.9651 \\
\hline & 1.7552 & $39.2958^{* * *}$ & 1.3774 & $17.0195^{* * *}$ & -1.0090 & $21.6993^{* * *}$ \\
\hline \multirow[t]{2}{*}{ Food items and agricultural products } & 0.0056 & 0.9137 & 0.0046 & 1.0029 & -0.0136 & 0.9990 \\
\hline & 0.3944 & $8.4748^{* * *}$ & 0.1640 & $3.4491^{* * *}$ & -0.3750 & $3.7951^{* * * *}$ \\
\hline \multirow[t]{2}{*}{ Minerals and ores } & 0.0081 & 1.2058 & -0.0214 & 1.3622 & -0.0315 & 1.6710 \\
\hline & 0.3050 & $5.9542^{* * *}$ & -0.5691 & $3.4885^{* * *}$ & -0.4111 & $2.9963^{* *}$ \\
\hline
\end{tabular}

Table 3. Single index model estimates for four export portfolios for five-year rolling periods.

\begin{tabular}{|c|c|c|c|c|c|c|c|c|}
\hline \multicolumn{9}{|c|}{$\begin{array}{l}\text { Quarterly returns for four export portfolios. The first row gives the value of the coefficients. The second row gives the t-stat } \\
\text { for the coefficients. The critical values for t-stat for DF = } 17 \text { are } 2.8982(1 \%), 2.1098(5 \%) \text { and } 1.7396(10 \%) \text { for } 1988-1992 \text {, } \\
\text { and for DF = 18, } 2.8784(1 \%), 2.1009(5 \%) \text { and } 1.7341(10 \%) \text {. These are designated by }{ }^{* * *} \text {, }^{* *} \text { and }{ }^{*} \text { respectively. }\end{array}$} \\
\hline \multirow{2}{*}{$\begin{array}{l}\text { Sample } \\
\text { Period }\end{array}$} & \multicolumn{2}{|c|}{ Fuel Products } & \multicolumn{2}{|c|}{ Manufactured Products } & \multicolumn{2}{|c|}{ Agricultural Products } & \multicolumn{2}{|c|}{ Minerals \& Ores } \\
\hline & Intercept & Slope & Intercept & Slope & Intercept & Slope & Intercept & Slope \\
\hline \multirow[t]{2}{*}{ 1988-1992 } & 0.0265 & 0.7858 & 0.0042 & 0.9096 & 0.0155 & 0.1155 & 0.0021 & 0.6651 \\
\hline & 0.9514 & $2.0239^{*}$ & 1.7713 & $27.8383^{* * *}$ & 0.6930 & 0.3702 & 0.1187 & $2.7127^{* *}$ \\
\hline \multirow[t]{2}{*}{ 1989-1993 } & 0.0204 & 1.1504 & 0.0026 & 0.9038 & 0.0101 & 0.1754 & 0.0038 & 0.3032 \\
\hline & 0.8095 & $3.0507^{* * *}$ & 0.9921 & $23.0054^{* * *}$ & 0.5003 & 0.5781 & 0.2068 & 1.0999 \\
\hline \multirow[t]{2}{*}{ 1990-1994 } & 0.0082 & 1.2320 & 0.0035 & 0.9284 & 0.0214 & 0.2445 & 0.0150 & 0.2651 \\
\hline & 0.3285 & $3.4970^{* * *}$ & 1.3003 & $24.6511^{* * *}$ & 1.0589 & 0.8561 & 0.8258 & 1.0327 \\
\hline \multirow[t]{2}{*}{ 1991-1995 } & -0.0018 & 0.9824 & 0.0024 & 0.9531 & 0.0110 & 0.5081 & 0.0215 & 0.0483 \\
\hline & -0.0921 & $3.3220^{* * *}$ & 1.0079 & $26.6668^{* * *}$ & 0.5004 & 1.5209 & 1.2093 & 0.1793 \\
\hline \multirow[t]{2}{*}{ 1992-1996 } & 0.0259 & 0.7486 & -0.0010 & 0.9966 & 0.0248 & 0.4773 & 0.0292 & -0.0700 \\
\hline & 1.6123 & $2.8412^{* *}$ & -0.4357 & $25.8767^{* * *}$ & 1.1688 & 1.3733 & 1.6921 & -0.2472 \\
\hline \multirow[t]{2}{*}{ 1993-1997 } & 0.0026 & 0.9271 & -0.0007 & 0.9939 & 0.0185 & 0.6744 & 0.0320 & -0.1639 \\
\hline & 0.2005 & $4.6862^{* * *}$ & -0.3231 & $31.5451^{* * *}$ & 0.8135 & $1.9262^{*}$ & 1.6404 & -0.5469 \\
\hline \multirow[t]{2}{*}{ 1994-1998 } & -0.0080 & 1.0021 & 0.0005 & 0.9949 & 0.0101 & 0.8563 & 0.0238 & 0.1621 \\
\hline & -0.5486 & $4.4041^{* * *}$ & 0.2625 & $35.6435^{* * *}$ & 0.3641 & $1.9901^{*}$ & 1.2639 & 0.5536 \\
\hline \multirow[t]{2}{*}{ 1995-1999 } & 0.0025 & 1.2186 & -0.0006 & 1.0025 & 0.0045 & 0.9204 & 0.0142 & 0.1268 \\
\hline & 0.1532 & $4.5051^{* * *}$ & -0.2985 & $31.2258^{* * *}$ & 0.1627 & $1.9787^{*}$ & 0.8090 & 0.4329 \\
\hline \multirow[t]{2}{*}{$1996-2000$} & 0.0151 & 1.2731 & -0.0011 & 1.0158 & 0.0043 & 0.8459 & 0.0079 & 0.0049 \\
\hline & 0.9204 & $4.3772^{* * *}$ & -0.5725 & $28.7913^{* * *}$ & 0.1661 & $1.8583^{*}$ & 0.4993 & 0.0175 \\
\hline \multirow[t]{2}{*}{$1997-2001$} & -0.0048 & 1.4357 & -0.0002 & 1.0014 & -0.0036 & 0.8955 & 0.0036 & 0.0522 \\
\hline & -0.2917 & $4.6587^{* * *}$ & -0.1278 & $29.8860^{* * *}$ & -0.1507 & $2.0136^{*}$ & 0.2463 & 0.1944 \\
\hline \multirow[t]{2}{*}{ 1998-2002 } & 0.0022 & 1.6105 & -0.0012 & 0.9839 & 0.0013 & 0.8238 & 0.0019 & 0.4478 \\
\hline & 0.1484 & $6.0714^{* * *}$ & -0.6823 & $29.7929^{* * *}$ & 0.0551 & $2.0015^{*}$ & 0.1680 & $2.1838^{* *}$ \\
\hline
\end{tabular}




\begin{tabular}{|c|c|c|c|c|c|c|c|c|}
\hline \multicolumn{9}{|c|}{ Continued } \\
\hline \multirow[t]{2}{*}{$1999-2003$} & 0.0134 & 1.3477 & -0.0020 & 1.0036 & 0.0041 & 0.6558 & 0.0087 & 0.5126 \\
\hline & 0.9408 & $5.1450^{* * *}$ & -1.0133 & $28.1576^{* * *}$ & 0.2433 & $2.1282^{* *}$ & 0.6649 & $2.1292^{* *}$ \\
\hline \multirow[t]{2}{*}{ 2000-2004 } & 0.0095 & 1.1949 & -0.0015 & 0.9814 & 0.0079 & 0.7150 & 0.0220 & 0.5424 \\
\hline & 0.6749 & $4.4766^{* * *}$ & -0.8126 & $27.2181^{* * *}$ & 0.6242 & $3.0035^{* * *}$ & 1.1908 & 1.5526 \\
\hline \multirow[t]{2}{*}{ 2001-2005 } & 0.0061 & 1.2675 & -0.0011 & 0.9716 & 0.0053 & 0.8327 & 0.0306 & 0.6849 \\
\hline & 0.4226 & $4.7928^{* * *}$ & -0.5745 & $28.9332^{* * *}$ & 0.3912 & $3.3842^{* * *}$ & 1.7466 & $2.1404^{* *}$ \\
\hline \multirow[t]{2}{*}{$2002-2006$} & 0.0309 & 0.8030 & -0.0008 & 0.9842 & -0.0083 & 1.1443 & 0.0432 & 0.5638 \\
\hline & 2.0851 & $3.0636^{* * *}$ & -0.3381 & $24.0352^{* * *}$ & -0.5943 & $4.6350^{* * *}$ & 1.9281 & 1.4231 \\
\hline \multirow[t]{2}{*}{$2003-2007$} & 0.0290 & 0.8691 & -0.0005 & 0.9689 & -0.0144 & 1.4571 & 0.0511 & 0.4316 \\
\hline & 1.7235 & $2.8891^{* * *}$ & -0.1698 & $18.7624^{* * *}$ & -0.8534 & $4.8194^{* * *}$ & 2.1750 & 1.0269 \\
\hline \multirow[t]{2}{*}{ 2004-2008 } & 0.0176 & 1.3581 & 0.0009 & 0.8909 & 0.0069 & 1.0510 & 0.0192 & 0.9612 \\
\hline & 1.3206 & $7.0281^{* * *}$ & 0.4643 & $30.9802^{* * *}$ & 0.5011 & $5.2990^{* * *}$ & 0.9410 & $3.2507^{* * * *}$ \\
\hline \multirow[t]{2}{*}{ 2005-2009 } & 0.0078 & 1.5312 & 0.0011 & 0.9228 & 0.0066 & 0.9627 & 0.0234 & 0.9311 \\
\hline & 0.6269 & $10.9521^{* * *}$ & 0.5308 & $39.6005^{* * *}$ & 0.4535 & $5.8803^{* * *}$ & 1.3841 & $4.8973^{* * *}$ \\
\hline \multirow[t]{2}{*}{$2006-2010$} & -0.0013 & 1.4893 & 0.0018 & 0.9292 & 0.0106 & 0.9419 & 0.0134 & 0.9599 \\
\hline & -0.1085 & $10.8266^{* * *}$ & 0.7498 & $35.1775^{* * *}$ & 0.7250 & $5.8509^{* * *}$ & 0.7650 & $4.9714^{* * *}$ \\
\hline \multirow[t]{2}{*}{$2007-2011$} & 0.0097 & 1.5218 & 0.0006 & 0.9191 & 0.0124 & 0.9806 & 0.0067 & 0.9104 \\
\hline & 0.8261 & $11.6561^{* * *}$ & 0.2270 & $29.9281^{* * *}$ & 0.7224 & $5.1548^{* * *}$ & 0.4236 & $5.1862^{* * *}$ \\
\hline \multirow[t]{2}{*}{$2008-2012$} & 0.0081 & 1.4913 & 0.0011 & 0.9252 & 0.0055 & 0.9006 & 0.0064 & 0.9624 \\
\hline & 0.6588 & $10.4789^{* * *}$ & 0.3879 & $27.4868^{* * *}$ & 0.3219 & $4.5428^{* * *}$ & 0.4302 & $5.5602^{* * *}$ \\
\hline
\end{tabular}

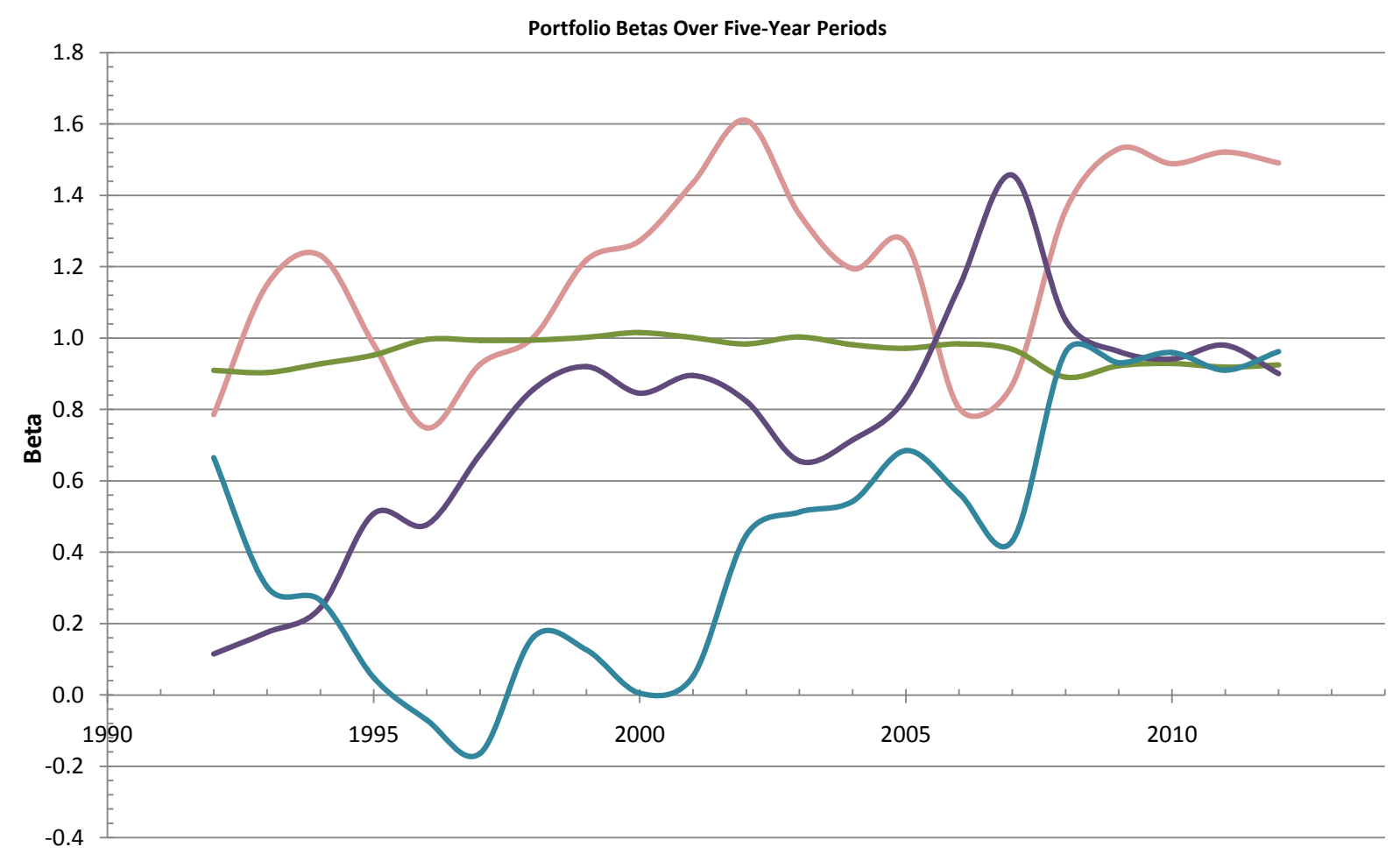

Five-Year-End

$\longrightarrow$ Oil —Mfg Food —Ores

Figure 1. Porfolio betas for rolling five-year periods. 
minerals, have tended to converge to a narrow range. 5) The significance of $t$-statistics bears the earlier observations out.

Table 4 repeats the format of Table 2 but gives the performance ratios. The Sharpe and Treynor ratios are reported for the individual countries and the portfolios. Because we are using the single index model it seems more appropriate to focus the attention on the Treynor ratio. Countries in export portfolios comprised of fuel products and ores and metals show returns above the global rate. Several countries in the manufactured-products export portfolio, such as France, the UK, Portugal and Japan, and several countries in food items and agricultural products export portfolio, such as Malawi and Côte d'Ivoire show returns lower than the global rate.

Figures 2-5 depict three-graphs per portfolio corresponding to three sample periods. Figure 2 shows the Treynor ratios for fuel products countries and portfolio, Figure 3 for manufactured-products countries and portfolio, Figure 4 for food items and agricultural-products countries and portfolio, and Figure 5 for ores and minerals countries and portfolio. Rarely do we see negative Treynor ratios: for 1989-1998 for fuel products countries (Iraq), and for ores and minerals countries (Zambia, Suriname, Guyana and Sierra Leone). We suspect that these negative numbers must somehow reflect unique and temporary conditions and circumstances of these countries (e.g., a drop in prices for these natural-resource-based commodities); nevertheless all of them moved into the positive territory for the following decade.
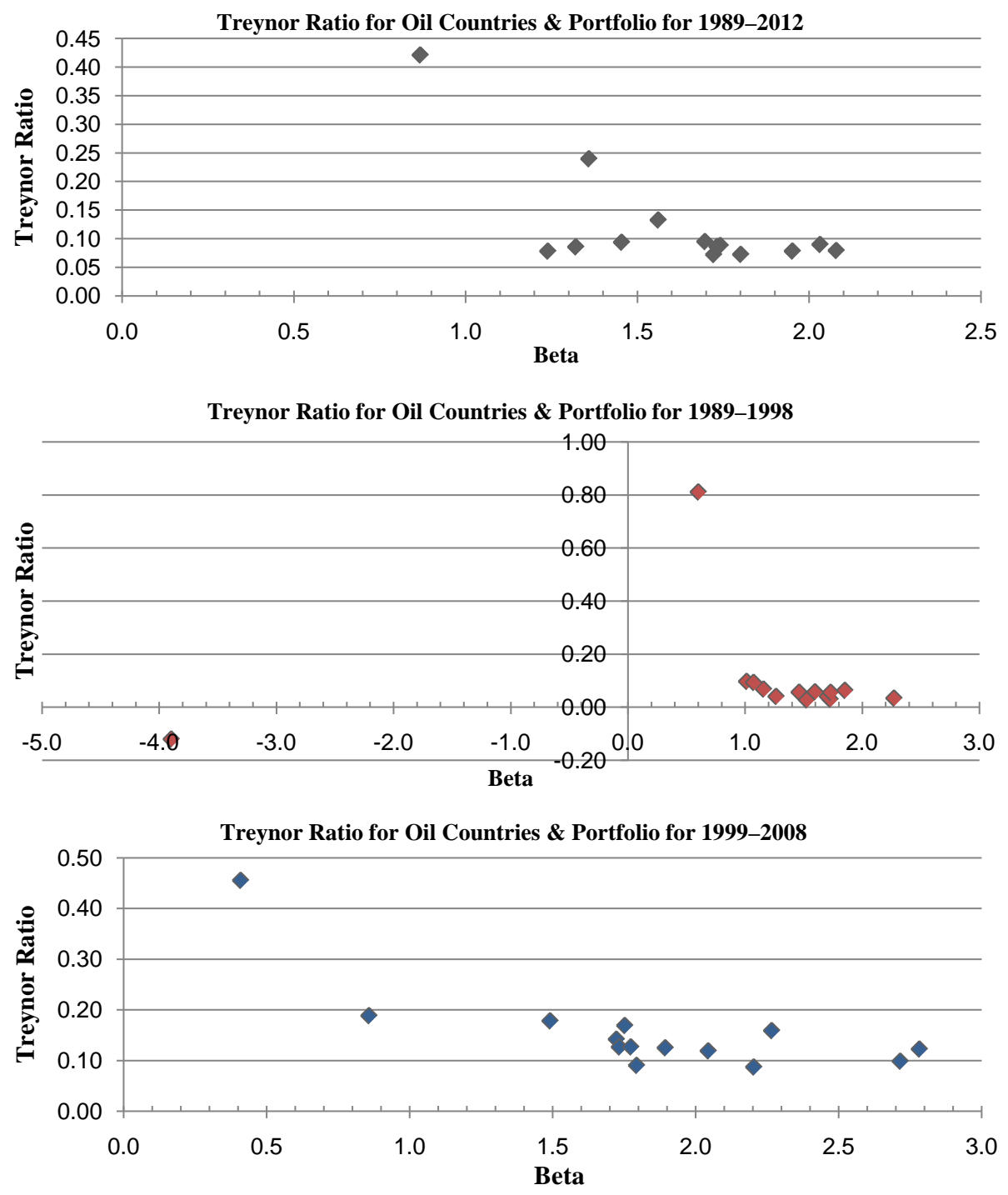

Figure 2. Treynor ratio for oil countries and portfolio. 

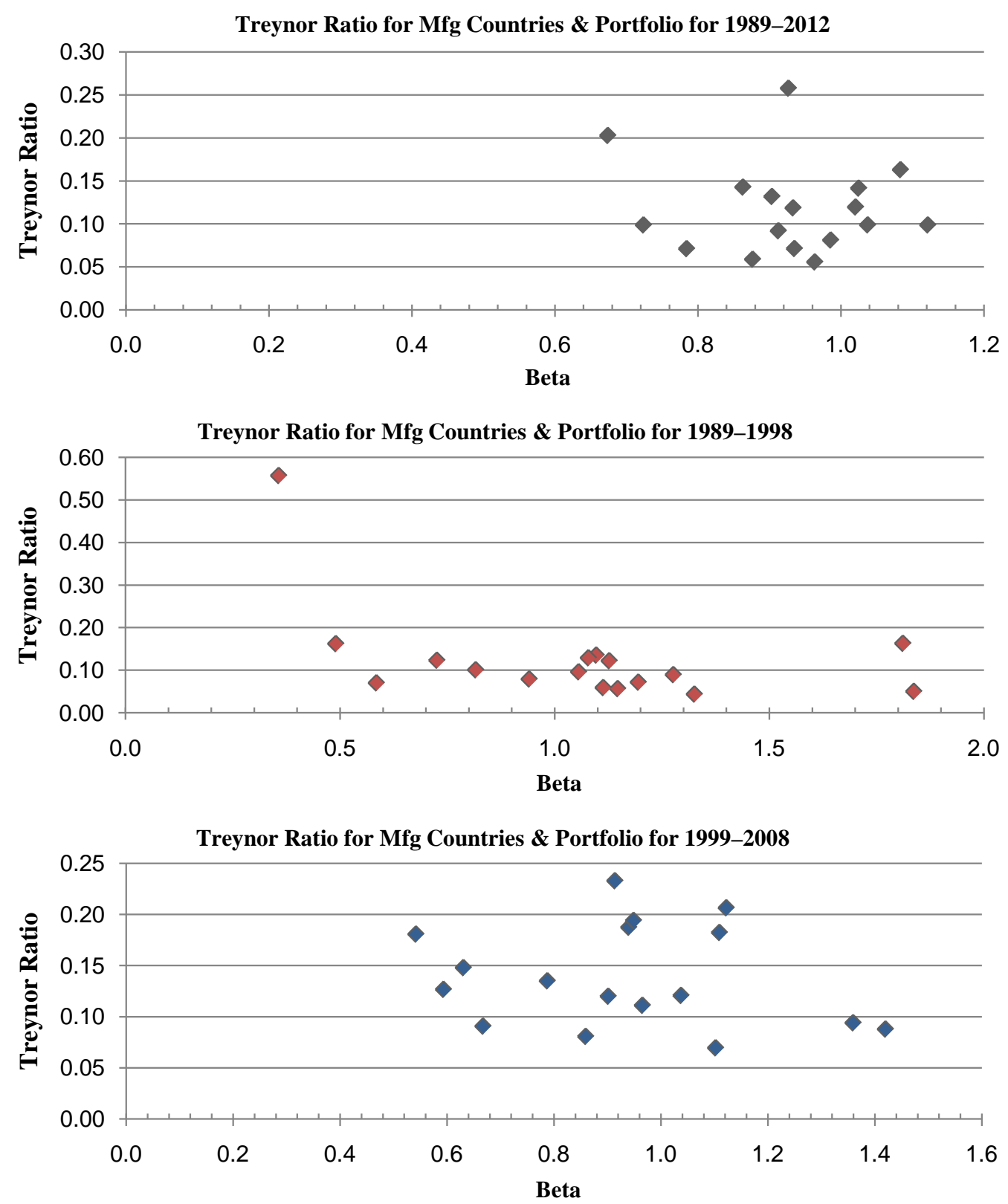

Figure 3. Treynor ratio for manufacturing countries and portfolio.

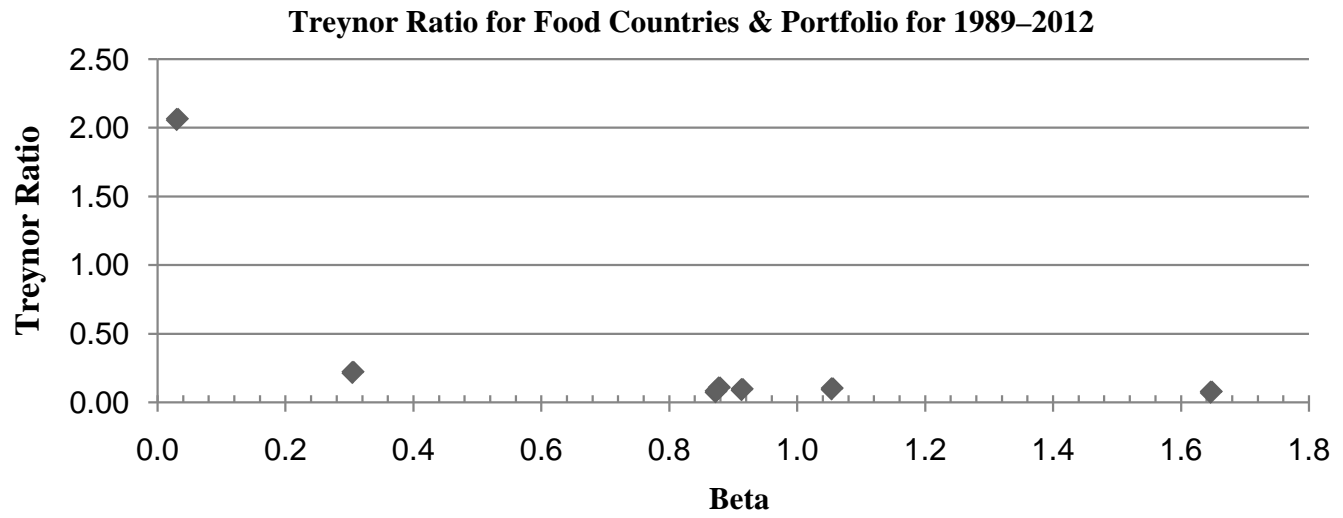



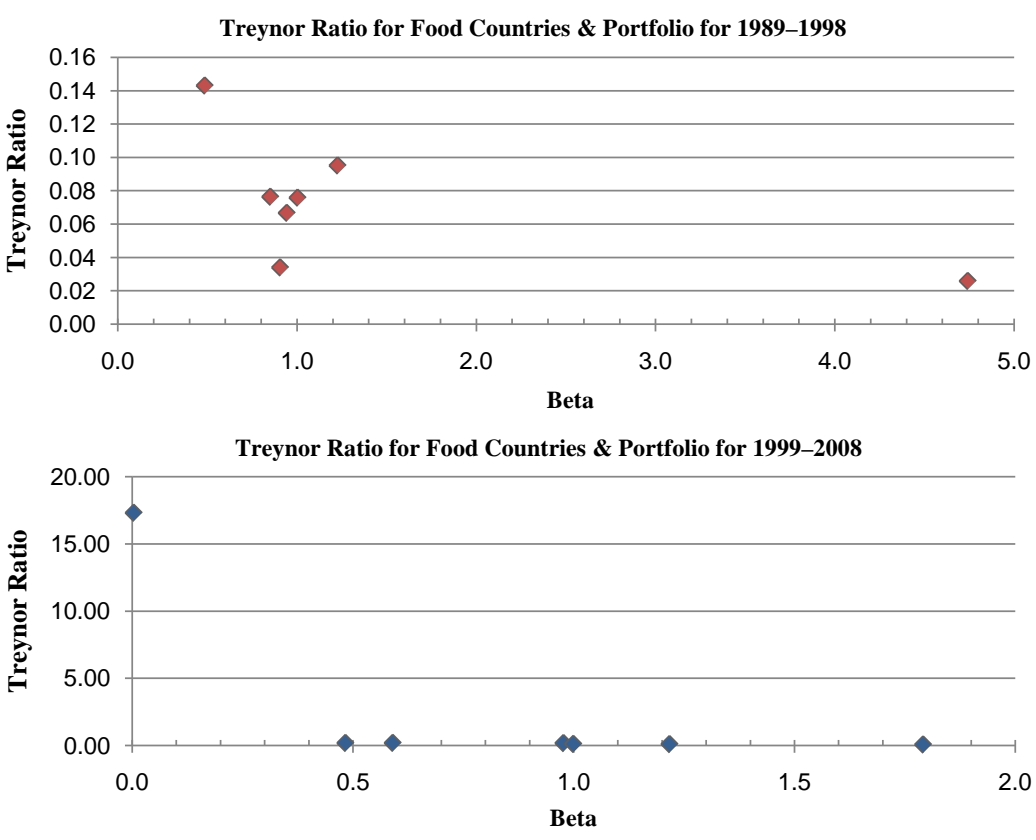

Figure 4. Treynor ratio for food countries and portfolio.

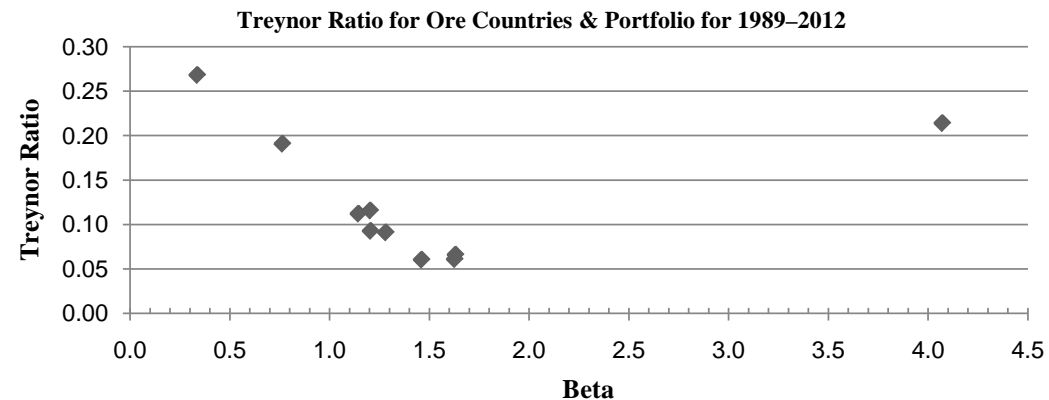

Treynor Ratio for Ore Countries \& Portfolio for 1989-1998
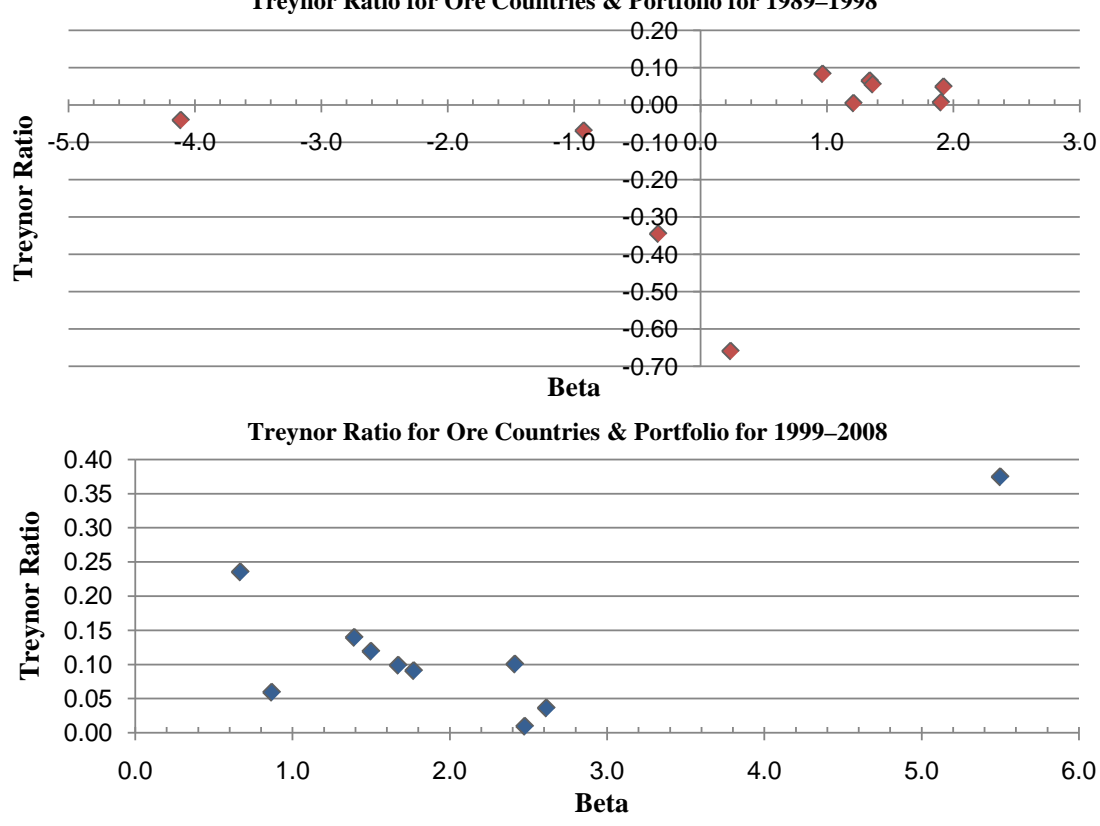

Figure 5. Treynor ratio for ore countries and portfolio. 
Table 4. (Modified) Sharpe and Treynor ratios for the countries of a portfolio and the portfolio. (a) Fuel-products-exporting portfolio; (b) Manufactured-products-exporting portfolio; (c) Food items and agricultural products-exporting portfolio; (d) Minerals-and-ores-exporting portfolio.

(a)

\begin{tabular}{cccccccc}
\hline & \multicolumn{2}{c}{ Annual returns for 13 countries in the portfolio. } & & \\
\hline & \multicolumn{2}{c}{ Sample period $1989-2012$} & Sample period 1989-1998 & \multicolumn{2}{c}{ Sample period 1999-2008 } \\
\hline Country & Sharpe ratio & Treynor ratio & Sharpe ratio & Treynor ratio & Sharpe ratio & Treynor ratio \\
\hline Angola & 0.6329 & 0.0897 & 0.2585 & 0.0295 & 1.3199 & 0.1591 \\
Iraq & 0.3627 & 0.4208 & 0.3093 & -0.1208 & 0.7781 & 0.1227 \\
Brunei Darussalam & 0.4797 & 0.0855 & 0.1884 & 0.0401 & 1.3018 & 0.4556 \\
Nigeria & 0.5101 & 0.0791 & 0.3014 & 0.0562 & 0.7783 & 0.0987 \\
Qatar & 0.8641 & 0.1325 & 0.6507 & 0.0969 & 1.1893 & 0.1692 \\
Kuwait & 0.3385 & 0.2395 & 0.3271 & 0.8117 & 1.1838 & 0.1191 \\
República Bolivariana de Venezuela & 0.4949 & 0.0721 & 0.4105 & 0.0575 & 0.7545 & 0.0872 \\
Saudi Arabia & 0.5934 & 0.0781 & 0.3115 & 0.0336 & 1.1946 & 0.1421 \\
Islamic Republic of Iran & 0.4960 & 0.0724 & 0.1859 & 0.0270 & 1.2128 & 0.1783 \\
Norway & 0.6405 & 0.0780 & 0.4614 & 0.0399 & 1.7169 & 0.1886 \\
Russian Federation & 0.7299 & 0.0948 & 0.5824 & 0.0631 & 1.1627 & 0.1268 \\
United Arab Emirates & 0.7170 & 0.0879 & 0.5242 & 0.0677 & 1.2946 & 0.1252 \\
Bolivia & 0.6329 & 0.0936 & 0.4997 & 0.0930 & 0.8372 & 0.0905 \\
Portfolio & 0.7087 & 0.0860 & 0.5365 & 0.0557 & 1.2791 & 0.1269 \\
\hline
\end{tabular}

(b)

\begin{tabular}{ccccccc}
\hline \multicolumn{5}{c}{ Annual returns for 16 countries in the portfolio. } \\
\hline & \multicolumn{7}{c}{ Sample period 1989-2012 } & \multicolumn{2}{c}{ Sample period 1989-1998 } & \multicolumn{2}{c}{ Sample period 1999-2008 } \\
\hline Country & Sharpe ratio & Treynor ratio & Sharpe ratio & Treynor ratio & Sharpe ratio & Treynor ratio \\
\hline China, P.R.: Mainland & 1.4066 & 0.1629 & 1.4934 & 0.1353 & 2.2668 & 0.2064 \\
Japan & 0.4636 & 0.0555 & 0.6041 & 0.0700 & 0.8122 & 0.0696 \\
Republic of Korea & 0.8592 & 0.0987 & 0.8412 & 0.0717 & 1.1464 & 0.0941 \\
Germany & 0.5907 & 0.0711 & 0.5365 & 0.0436 & 1.2925 & 0.1351 \\
Turkey & 1.0140 & 0.1317 & 1.3401 & 0.1231 & 1.5793 & 0.1874 \\
Mexico & 0.9603 & 0.2028 & 1.3419 & 0.5569 & 1.1934 & 0.1807 \\
Thailand & 1.0874 & 0.1427 & 1.1335 & 0.1289 & 1.5447 & 0.1208 \\
Singapore & 0.8325 & 0.0986 & 0.9484 & 0.0893 & 1.0669 & 0.0879 \\
United States & 0.8441 & 0.0986 & 1.7691 & 0.1621 & 0.9164 & 0.0808 \\
Malaysia & 0.9538 & 0.1185 & 1.3168 & 0.1220 & 1.2991 & 0.1200 \\
Vietnam & 0.8445 & 0.2578 & 0.6942 & 0.1628 & 2.5998 & 0.2328 \\
India & 1.1798 & 0.1414 & 1.1601 & 0.0959 & 2.0796 & 0.1941 \\
Portugal & 0.6235 & 0.0810 & 0.6400 & 0.0501 & 1.0921 & 0.1480 \\
Poland & 0.8686 & 0.1195 & 0.6773 & 0.1007 & 1.8155 & 0.1823 \\
France & 0.5840 & 0.0710 & 0.7109 & 0.0565 & 1.1511 & 0.1267 \\
United Kingdom & 0.4931 & 0.0587 & 0.7713 & 0.0590 & 0.8492 & 0.0908 \\
Portfolio & 0.8946 & 0.0918 & 1.1387 & 0.0790 & 1.4631 & 0.1111 \\
\hline
\end{tabular}


(c)

\begin{tabular}{|c|c|c|c|c|c|c|}
\hline \multicolumn{7}{|c|}{ Annual returns for six countries in the portfolio. } \\
\hline \multirow[b]{2}{*}{ Country } & \multicolumn{2}{|c|}{ Sample period 1989-2012 } & \multicolumn{2}{|c|}{ Sample period 1989-1998 } & \multicolumn{2}{|c|}{ Sample period 1999-2008 } \\
\hline & Sharpe ratio & Treynor ratio & Sharpe ratio & Treynor ratio & Sharpe ratio & Treynor ratio \\
\hline Malawi & 0.3954 & 2.0613 & 0.3075 & 0.0667 & 0.3982 & 17.3003 \\
\hline Uruguay & 0.6747 & 0.1036 & 0.9642 & 0.1431 & 0.6067 & 0.0600 \\
\hline New Zealand & 0.6066 & 0.0773 & 0.3150 & 0.0340 & 1.4116 & 0.1777 \\
\hline Uganda & 0.3025 & 0.0733 & 0.2012 & 0.0258 & 1.2045 & 0.1650 \\
\hline Côte d'Ivoire & 0.4984 & 0.2171 & 0.3960 & 0.0764 & 0.6536 & 0.1740 \\
\hline Argentina & 0.7848 & 0.0976 & 1.0162 & 0.0951 & 0.9140 & 0.0897 \\
\hline Portfolio & 0.7904 & 0.0920 & 0.8563 & 0.0758 & 1.1064 & 0.1039 \\
\hline
\end{tabular}

(d)

\begin{tabular}{ccccccc}
\hline \multicolumn{4}{c}{ Annual returns for nine countries in the portfolio. } & & \\
& \multicolumn{1}{c}{ Sample period $1989-2012$} & \multicolumn{2}{c}{ Sample period 1989-1998 } & \multicolumn{2}{c}{ Sample period 1999-2008 } \\
\hline Country & Sharpe ratio & Treynor ratio & Sharpe ratio & Treynor ratio & Sharpe ratio & Treynor ratio \\
\hline Zambia & 0.3606 & 0.1156 & 0.1699 & -0.0686 & 0.5897 & 0.1003 \\
Suriname & 0.2742 & 0.1908 & 0.2224 & -0.0403 & 0.3243 & 0.0361 \\
Democratic Republic of Congo & 0.3538 & 0.0659 & 0.0615 & 0.0073 & 0.5457 & 0.2352 \\
Chile & 0.6792 & 0.0910 & 0.6451 & 0.0492 & 0.8231 & 0.0907 \\
Peru & 0.8095 & 0.1121 & 0.5786 & 0.0654 & 1.3537 & 0.1394 \\
Mali & 0.3091 & 0.0608 & 0.4089 & 0.0835 & 0.0686 & 0.0093 \\
Mauritania & 0.4521 & 0.0603 & 0.0448 & 0.0050 & 1.0414 & 0.1191 \\
Guyana & 0.7354 & 0.2682 & 0.8117 & -0.3448 & 0.5114 & 0.0591 \\
Sierra Leone & 0.2218 & 0.2140 & -0.4409 & -0.6591 & 0.3417 & 0.3744 \\
Portfolio & 0.7144 & 0.0927 & 0.6297 & 0.0555 & 0.9525 & 0.0986 \\
\hline
\end{tabular}

We can state the following: Examining the betas, Treynor ratios, and Sharpe ratios, we conclude that exports of a country dominated by the manufactured-product-category are the most stable, i.e., with lowest instability. Additionally they have the best risk-return tradeoff. Exports of a country dominated by a natural-resource-based category do not do so well in terms of stability or risk-return tradeoff.

The next section provides some caveats for interpretation and discusses policy implications as well as future research directions.

\section{Caveats, Implications for Policies and Future Research}

The results mentioned in the earlier section are as more or less expected. Yet numerous cautions must be considered.

Recognize that we have not used the Markowitz model of constructing optimal portfolios. The Markowitz model needs both a full variance-covariance matrix and returns of the assets (here countries) in expectations terms. The outcome of the Markowitz model is an optimal portfolio where the optimality is defined as follows: Maximize a portfolio's rate of return given a level of risk in standard deviation or minimize a portfolio's risk in standard deviation given a level of portfolio return. The Markowitz model is not an equilibrium asset-pricing model. 
We are using the single-index model which is the ex post counterpart of the ex ante asset-pricing model designated as CAPM. The performance evaluation measurements due to Treynor and Sharpe do use the building blocks of the single index model. This explains the use of the single index model by international trade scholars and agriculture economists to study phenomena in their subject areas.

Does the above mean that the interpretation of the results is any less valid? The answer is obvious: the interpretation of results remains valid. We are successful in demonstrating that conventional wisdom about manufacturing products and their stabilizing role in an economy is the correct one. The caveat, however, is that one day soon this conventional wisdom will be overturned. The manufacturing power houses of the USA, Japan, a few countries in Western Europe have encountered economic turbulence whose severity has not been reduced by their industrial and manufacturing base or the domination by manufactured products in their exports. The reason is easy to spot: The manufacturing of many products has been "commoditized". A majority of the manufacturing-oriented countries have lost the monopoly rents they used to be able to extract through high amounts of exports. This actually is the most important reason for the USA to start concentrating on high-engineered goods and specialized manufacturing.

An additional reason is the rise of "knowledge economy" or "service economy". Countries going through this change are most likely to see the earnings on exports of manufactured products diminish and volatility increase.

Some of the other caveats concern the aggregate nature of export portfolios. The results would be accentuated further if the four portfolios included only the categorical exports instead of all exports of the countries included in the sample.

Implications for economic policy present a difficulty. On one hand we have demonstrated that exports of manufactured products-dominant countries are more stable than those of non-manufactured products-dominant countries. Yet we do not advocate any particular industrial policy. Any free-market-oriented financial economist would be against a government-sponsored industrial policy. Additionally, as mentioned earlier, the advantage of a majority of the "run-of-the-mill" manufactured products has dissipated and will be reflected in data in the future, unless, of course, the business sectors of the affected countries move to specialized engineering products.

The question of export diversification remains unanswerable. Camanho da Costa Neto and Romeu [78] (p. 1) investigate whether export diversification softens the impact of the global financial crisis using a sample of Latin American countries and they conclude that "increasing the diversity of both export sectors and export products within sectors ... reduces the quarterly decline in exports".

The question "What should countries whose exports are dominated by natural-resource-based products do?" remains exceedingly difficult to answer. Commodities have their own price cycles and associated ebbs and flows of demand. An intensive agriculture, extractive industry and petroleum industry have major environmental and health costs which have become difficult to pass along to others as "externalities". Populaces and their governments demand that industries "internalize" these costs one way or other; consequently the costs of these commodities could rise beyond a sustainable level. Unless there arises a "fair" allocation of these costs between extracting countries and manufacturing countries resulting in better "terms of trade", accounting fully for hitherto-ignored costs, economic development across the world in a smooth and orderly manner is unlikely. The world trade organizations have thus far failed to address these concerns adequately. This in turn has given rise to numerous trading blocs and regional free-trade agreements.

Implications for business firms operating in these different industries and different countries face challenges which will prove to be difficult to overcome. The days of vertical integration are long gone. Firms can try as much as horizontal integration as possible without inviting the claims of monopoly power and attendant intense scrutiny. We are afraid that this will not provide solace to firms, be they in a single country or in multiple countries. The firms would be well-advised to keep to their core competence and continue to innovate in both products and production technology while reducing the full costs of production. The firms in countries whose exports are dominated by non-manufactured products face altogether different challenges. As the manufacturing technology improves, the demand for raw materials will diminish. The exports of agricultural products are likely to continue unabated given the nourishment requirements of still-increasing population of the world. How should the firms adjust to these changes will remain the topic of discussion of many a scholars.

The future of research in this area is bright. Methodological and data improvements would yield promising results. More sophisticated econometric methods could yield deeper results leading to more nuanced interpretation. Recall that the sample period for returns in our study is 1989-2012, the first decade is 1989-1998 and the 
second decade is 1999-2008. Thus, the second decade does not include the full impact of global financial crisis. Therefore, a welcome extension would be to use an additional sub-period, say 2009-2018, to incorporate the full brunt of the financial crisis. One, however, must wait for the data to become available. Diversification of a) export sectors, b) products within export sectors and c) trading partners need to explored in imaginative ways. This could be a topic of another research study.

Governments, governmental entities and firms are hungry for suggestions for economic development. Undoubtedly, scholars working in this area face numerous challenges because of the sheer scale of problems and potential. Increasing global trade is here to stay. How this trade benefits the trading partners remains to be seen. Deeper analyses of global trading patterns, their impact on GDP and per capita income, on environment and health, on cross-border relations, etc. are expected to remain in vogue for many years to come.

\section{Conclusions}

Section 5 (Caveats, implications for policies and future research) of this article discussed in detail limitations of the empirical work, important caveats in the interpretation of results, policy implications for both business firms and countries as well as suggestions for future research directions. Section 4 (Results) of this article discussed the results of the empirical method and their interpretation. Section 3 (Data, methods, hypotheses and expected results) of this article discussed the empirical process. Section 2 (Literature review) of this article discussed various strands of literature that bear upon the empirical design of the study. Section 1 (Introduction) of this article provided the motivation for the research study. Therefore, this concluding section summarizes the results and emphasizes their significance.

It is significant that this study utilizes the single index model to assess the performance of four major categories of exported products. The single index model enables us to evaluate the performance of a country's export sector in terms of risk-return tradeoff, i.e., Treynor and Sharpe measures of performance inform us whether the return on an export portfolio is commensurate with risk inherent in the portfolio. Because a country ought to be more interested in fluctuations of its exports in relation to those of the total world exports, the Treynor ratio is more appropriate than the Sharpe ratio. The results indicate that portfolios comprised of exports dominated by manufactured products and food items and agricultural products are superior from a risk-return perspective than those dominated by fuel products and ores and minerals. The results of this study validate the intuitive and conventional wisdom that portfolios comprised of manufactured products have a superior performance than portfolios comprised of non-manufactured products. A subsidiary result is that the portfolio dominated by exports of food items and agricultural products has superior performance than the portfolio dominated by exports of fuel products and ores and minerals. It is significant that this study actually empirically demonstrates the validity of the conventional wisdom, as all of us know that conventional wisdom however intuitive is often not correct. Nevertheless, as Section 5 points out, it is significant to aver that this conventional wisdom may not remain correct for very long. The primary reasons given for this expectation are: 1) as manufactured products and manufacturing technology itself become commoditized the advantage of being an exporter of manufactured products diminishes and is expected to remain small and 2) as the current developed (and industrialized) countries become economies dominated by knowledge/information and services sectors the share of manufacturing in their economies diminishes and is expected to remain small.

Our concerns are shared by global financial and economic organizations. Traditionally statistics have been collected for exports of merchandise, but not for value-added or services- or knowledge-exports. The global organizations were alerted to this statistical lacuna by the repeated attempts of Western countries to "open up" the securities markets, insurance markets, banking markets, etc. of the less-developed countries. The effort to collect statistics on service- and knowledge-exports will need more time and talent to bear fruits. We would be deeply interested readers if our study were replicated with an expanded data set. It is significant for policy-makers to recognize that the instability of export earnings and the volatility of exports are the results of fiscal and financial policies and of the stage of development; they are the most visible symptoms of economies undergoing transitions of developmental stages. Making exports the dominant focus of economic or industrial policies is unlikely to help in economic development. While diversification among exported merchandise and services may be considered important, the policy-makers must recognize that the goal of diversification in and of itself is of limited value; it is the numerous factors of socio-economic development that actually make exports of a variety of 
products and services possible.

\section{References}

[1] Beltramello, A., De Backer, K. and Moussiegt, L. (2012) The Export Performance of Countries within Global Value Chains (GVCs). OECD Science, Technology and Industry, Working Papers, OECD, Paris. http://www.ecb.europa.eu/home/pdf/research/compnet/Beltramello_DeBacker_Moussiegt_2012.pdf

[2] Al-Marhubi, F. (2000) Export Diversification and Growth: An Empirical Investigation. Applied Economics Letters, 7, 559-562. http://dx.doi.org/10.1080/13504850050059005

[3] Bhagwati, J.N. and Ramaswami, V.K. (1963) Domestic Distortions, Tariffs, and the Theory of Optimum Subsidy. Journal of Political Economy, 71, 44-50. http://dx.doi.org/10.1086/258733

[4] Songwe, V. and Winkler, D. (2012) Exports and Export Diversification in Sub-Saharan Africa: A Strategy for PostCrisis Growth. Africa Growth Initiative, Working Paper 3, December. Brookings Institution, Washington DC. http://www.brookings.edu/ /media/research/files/papers/2012/12/exports-africa-songwe/12-exports-africa-songwe.pdf

[5] UNCTAD (2011) The State of Commodity Dependence 2012. UNCTAD Special Unit on Commodities, Geneva. http://unctadxiii.org/en/SessionDocument/suc2011d8_en.pdf

[6] UNDP (2011) Export Dependence and Export Concentration. Towards Human Resilience: Sustaining MDG Progress in an Age of Economic Uncertainty, UNDP Bureau for Development Policy, New York.

http://www.undp.org/content/dam/undp/library/Poverty\%20Reduction/Towards_SustainingMDG_Web1005.pdf

[7] Smith, A. (1776) An Inquiry into Nature and Causes of the Wealth of Nations. 1937 Edition, Modern Library, New York.

[8] Ricardo, D. (1817) Principles of Political Economy and Taxation. John Murray, London.

[9] DeRosa, A. (1992) Increasing Export Diversification in Commodity Exporting Countries: A Theoretical Analysis. IMF Staff Papers, 39, 572-595.http://www.ifpri.org/sites/default/files/publications/derosa92_01.pdf http://dx.doi.org/10.2307/3867474

[10] Currie, L. (1971) The Exchange Constraint on Development-A Partial Solution to the Problem. Economic Journal, 81, 886-903.

[11] Michaely, M. (1962) Concentration in International Trade. North-Holland, Amsterdam.

[12] Michaely, M. (1977) Exports and Growth: An Empirical Investigation. Journal of Development Economics, 4, 49-53. http://dx.doi.org/10.1016/0304-3878(77)90006-2

[13] Meilak, C. (2008) Measuring Export Concentration: The Implications for Small States. Bank of Valletta Review, 37, 35-48. https://www.bov.com/documents/bov-review-37-paper-3

[14] Balassa, B. (1978) Exports and Economic Growth: Further Evidence. Journal of Development Economics, 5, $181-189$. http://dx.doi.org/10.1016/0304-3878(78)90006-8

[15] Chenery, H.B. and Strout, A.M. (1966) Foreign Assistance and Economic Development. American Economic Review, 56, 679-733.

[16] Myrdal, G. (1956) Development and Underdevelopment: A Note on the Mechanism of National and International Economic Inequality. National Bank of Egypt, Cairo.

[17] Prebisch, R. (1950) The Economic Development of Latin America and Its Principal Problems, United Nations Department of Economic Affairs, Economic Commission for Latin America (ECLA), New York. http://archivo.cepal.org/pdfs/cdPrebisch/002.pdf

[18] Samen, S. (2010) A Primer on Export Diversification: Key Concepts, Theoretical Underpinnings and Empirical Evidence. Growth and Crisis Unit, World Bank, Washington DC. https://blogs.worldbank.org/files/growth/EXPORT_DIVERSIFICATION_A_PRIMER_May2010\%281\%29.pdf

[19] Singer, H.W. (1964) International Development: Growth and Change. McGraw-Hill, New York.

[20] Heller, P.S. and Porter, R.C. (1978) Export and Growth: An Empirical Re-Investigation. Journal of Development Economics, 5, 191-193. http://dx.doi.org/10.1016/0304-3878(78)90007-X

[21] Ocampo, J.A. (2013) Super-Cycles of Commodity Prices since the Mid-Nineteenth Century. Presentation at the International Monetary Fund. https://www.imf.org/external/np/seminars/eng/2012/commodity/pdf/Ocampo.pdf

[22] Erten, B. and Ocampo, J.A. (2012) Super-Cycles of Commodity Prices since the Mid-Nineteenth Century. Working Paper 110, UN Department of Economic and Social Affairs, New York. http://www.un.org/esa/desa/papers/2012/wp110_2012.pdf

[23] Arnade, C. and Lee, D. (1990) Risk Aversion through Nontraditional Export Promotion Programs in Central America. US Department of Agriculture, Economic Research Service, Washington DC. 
[24] Helleiner, G.K. (1973) Manufactured Exports from Less Developed Countries and Multinational Firms. Economic Journal, 83, 21-47. http://dx.doi.org/10.2307/2231098

[25] Helleiner, G.K. (1973) Manufacturing for Export, Multinational Firms and Economic Development. World Development, 1, 13-21. http://dx.doi.org/10.1016/0305-750X(73)90073-9

[26] Helleiner, G.K. (1979) Structural Aspects of Third World Trade: Some Trends and Some Prospects. Journal of Development Studies, 15, 70-88. http://dx.doi.org/10.1080/00220387908421727

[27] Nurkse, R. (1961) International Trade Theory and Development Policy. In: Ellis, H.S., Ed., Development for Latin America, St. Martin’s Press, New York, 234-263

[28] Roemer, M. (1979) Resource-Based Industrialization in the Developing Countries: A Survey. Journal of Development Economics, 6, 163-202. http://dx.doi.org/10.1016/0304-3878(79)90012-9

[29] Hanson, G. (2010) Export Dependence in Developing Countries. University of California, San Diego and NBER. http://wise.xmu.edu.cn/Master/News/NewsPic/2010112417234402.pdf

[30] Díaz-Alejandro, C.F. (1974) Some Characteristics of Recent Export Expansion in Latin America. In: Giersch, H., Ed., The International Division of Labor: Problems and Perspectives, International Symposium, J.C.B. Mohr (Paul Siebeck), Tübingen, 215-236.

[31] Kirkpatrick, C.H. and Nixson, F.I. (1983) The Industrialization of Less Developed Countries. Manchester University Press, Manchester.

[32] Leibenstein, H. (1978) General X-Efficiency Theory and Economic Development. Oxford University Press, Oxford.

[33] Klinger, B. and Lederman, D. (2006) Innovation and Export Portfolios. World Bank Policy Research, Working Paper 3983, World Bank, Washington DC.

[34] Baldwin, R.E. (1963) Export Technology and Development from a Subsistence Level. Economic Journal, 73, 80-92. http://dx.doi.org/10.2307/2228404

[35] Gutiérrez de Piñeres, S.A. and Ferrantino, M. (1997) Export Diversification and Structural Dynamics in the Growth Process: The Case of Chile. Journal of Development Economics, 52, 375-391. http://dx.doi.org/10.1016/S0304-3878(96)00446-4

[36] Gutiérrez de Piñeres, S.A. and Ferrantino, M. (1999) Export Sector Dynamics and Domestic Growth: The Case of Colombia. Review of Development Economics, 3, 268-280. http://dx.doi.org/10.1111/1467-9361.00067

[37] Fung, K.C., García-Herrero, A. and Ospina, M.N. (2013) Latin America Commodity Export Concentration: Is There a China Effect? BBVA Working Paper, No.13/06, Banco Bilbao Vizcaya Argentaria (BBVA), Hong Kong. https://www.bbvaresearch.com/KETD/fbin/mult/WP_1306_tcm348-370671.pdf

[38] Persaud, S.C. and Meade, B.G.S. (2009) Trade and Development When Exports Lack Diversification: A Case Study from Malawi. USDA Economic Research Report 77, USDA, Oklahoma City. http://www.ers.usda.gov/media/155326/err77 1 .pdf

[39] Sannassee, R.V., Seetanah, B. and Lamport, M.J. (2014) Export Diversification and Economic Growth: The Case of Mauritius. In: Jansen, M., Jallab, M.S. and Smeets, M., Eds., Connecting to Global Markets-Challenges and Opportunities: Case Studies Presented by WTO Chair-Holders, Chapter 1, WTO, Geneva, 11-23. http://www.wto.org/english/res e/booksp e/cmark full e.pdf

[40] Hamed, K., Hadi, D. and Hossein, K. (2014) Export Diversification and Economic Growth in Some Selected Developing Countries. African Journal of Business Management, 8, 700-704. http://dx.doi.org/10.5897/AJBM2012.397

[41] Agosin, M.R. (2009) Export Diversification and Growth. CEPAL Review, 97, 115-131.

[42] Herzer, D. and Nowak-Lehnmann, F. (2006) What Does Export Diversification Do for Growth? An Econometric Analysis. Applied Economics, 38, 1825-1838. http://dx.doi.org/10.1080/00036840500426983

[43] Glezakos, C. (1973) Export Instability and Economic Growth: A Statistical Verification. Economic Development and Cultural Change, 21, 670-678. http://dx.doi.org/10.1086/450669

[44] Lim, D. (1976) Export Instability and Economic Growth: A Return to Fundamentals. Oxford Bulletin of Economics and Statistics, 38, 311-322. http://dx.doi.org/10.1111/j.1468-0084.1976.mp38004007.x

[45] Kenen, P.B. and Voivodas, C.S. (1972) Export Instability and Economic Growth. Kyklos, 25, 791-804. http://dx.doi.org/10.1111/j.1467-6435.1972.tb01082.x

[46] Stanley, D.L. (1999) Export Diversification as a Stabilization Strategy: The Central American Case Revisited. Journal of Developing Areas, 33, 531-548.

[47] Stanley, D.L. and Bunnag, S. (2001) A New Look at the Benefits of Diversification: Lessons from Central America. Applied Economics, 33, 1369-1383. http://dx.doi.org/10.1080/00036840010007498

[48] MacBean, A.I. (1966) Export Instability and Economic Development. Allen and Unwin, London. 
[49] Cadot, O., Carrère, C. and Strauss-Kahn, V. (2011) Export Diversification: What's behind the Hump? Review of Economics and Statistics, 93, 590-605. http://dx.doi.org/10.1162/REST_a_00078

[50] Dogruel, A.S. and Tekce, M. (2010) Trade Liberalization and Export Diversification in Selected MENA Countries. Topics in Middle Eastern and African Economies, 13, 1-24.

[51] Ferdous, F.B. (2011) Export Diversification in East Asian Economies: Some Factors Affecting the Scenario. International Journal of Social Science and Humanity, 1, 13-18. http://dx.doi.org/10.7763/IJSSH.2011.V1.3

[52] Kim, D. (2012) Export Diversification: Lessons from Korean Experience. Working Paper, Korea Development Institute. http://www.cieplan.org/media/publicaciones/archivos/302/Paper_de_Duol_Kim_Korea_Development_Institute_Rep_d e_Corea_en_ingles.pdf

[53] Brainard, W. and Cooper, R. (1968) Uncertainty and Diversification in International Trade. Food Research Institute Studies in Agricultural Economics, Trade, and Development, 8, 256-285.

[54] Massell, B.F. (1964) Export Concentration and Fluctuations in Export Earnings: A Cross-Section Analysis. American Economic Review, 54, 47-63.

[55] Massell, B.F. (1970) Export Instability and Economic Structure. American Economic Review, 60, 618-630.

[56] Love, J. (1979) A Model of Trade Diversification Based on the Markowitz Model of Portfolio Analysis. Journal of Development Studies, 15, 233-241. http://dx.doi.org/10.1080/00220387908421717

[57] Love, J. (1979) Trade Concentration and Export Instability. Journal of Development Studies, 15, 60-69. http://dx.doi.org/10.1080/00220387908421726

[58] Love, J. (1983) Concentration, Diversification and Earnings Instability: Some Evidence on Developing Countries’ Exports of Manufactures and Primary Products. World Development, 11, 787-793. http://dx.doi.org/10.1016/0305-750X(83)90091-8

[59] Love, J. (1986) Commodity Concentration and Export Earnings Instability: A Shift from Cross-Section to Time Series Analysis. Journal of Development Economics, 24, 239-248. http://dx.doi.org/10.1016/0304-3878(86)90090-8

[60] MacBean, A.I. and Nguyen, D.T. (1980) Commodity Concentration and Export Earnings Instability: A Mathematical Analysis. Economic Journal, 90, 354-362. http://dx.doi.org/10.2307/2231793

[61] Tuong, H.D. and Yeats, A. (1976) A Note on the Measurement of Trade Concentration. Oxford Bulletin of Economics and Statistics, 38, 299-309. http://dx.doi.org/10.1111/j.1468-0084.1976.mp38004006.x

[62] Kravis, I.B. (1970) Trade as a Handmaiden of Growth: Similarities between the Nineteenth and Twentieth Centuries. Economic Journal, 80, 850-872. http://dx.doi.org/10.2307/2229902

[63] Markowitz, H.M. (1952) Portfolio Selection. Journal of Finance, 7, 77-91.

[64] Markowitz, H.M. (1959) Portfolio Selection: Efficient Diversification of Investments. John Wiley \& Sons, New York.

[65] Sharpe, W.F. (1964) Capital Asset Prices: A Theory of Market Equilibrium under Conditions of Risk. Journal of Finance, 19, 425-442.

[66] Lintner, J. (1965) The Valuation of Risk Assets and the Selection of Risky Investments in Stock Portfolios and Capital Budgets. Review of Economics and Statistics, 47, 13-37. http://dx.doi.org/10.2307/1924119

[67] Blank, S.C. (1991) The Robustness of Single Index Models in Crop Markets: A Multiple Index Model Test. Western Journal of Agricultural Economics, 16, 259-267.

[68] Collins, R.A. and Barry, P.J. (1986) Risk Analysis with Single Index Portfolio Models: An Application to Farm Planning. American Journal of Agricultural Economics, 68, 152-161. http://dx.doi.org/10.2307/1241660

[69] Barry, P.J. (1980) Capital Asset Pricing and Farm Real Estate. American Journal of Agricultural Economics, 62, 549553. http://dx.doi.org/10.2307/1240213

[70] Gempesaw II., C.M., Tambe, A.M., Nayga Jr., R.M. and Toensmeyer, U.C. (1988) The Single Index Market Model in Agriculture. Northeastern Journal of Agricultural and Resource Economics, 17, 147-155.

[71] Turvey, C.G. and Driver, H.C. (1987) Systematic and Nonsystematic Risks in Agriculture. Canadian Journal of Agricultural Economics, 35, 387-401. http://dx.doi.org/10.1111/j.1744-7976.1987.tb02236.x

[72] De Gouvea, R., Kapelianis, D., Montoya, M.J.R. and Vora, G. (2014) An Export Portfolio Assessment of Regional Free Trade Agreements: A Mercosur and Pacific Alliance Perspective. Modern Economy, 5, 614-624. http://dx.doi.org/10.4236/me.2014.55058

[73] Di Giovanni, J. and Levchenko, A.A. (2011) The Risk Content of Exports: A Portfolio View of International Trade. In: Frankel, J. and Pissarides, C., Eds., NBER International Seminar on Macroeconomics 2011, University of Chicago Press, Chicago.

[74] Sharpe, W.F. (1966) Mutual Fund Performance. Journal of Business, 39, 119-138. http://dx.doi.org/10.1086/294846 
[75] Sharpe, W.F. (1975) Adjusting for Risk in Portfolio Performance Measurement. Journal of Portfolio Management, 1, 29-34. http://dx.doi.org/10.3905/jpm.1975.408513

[76] Sharpe, W.F. (1994) The Sharpe Ratio. Journal of Portfolio Management, 21, 49-58. http://dx.doi.org/10.3905/jpm.1994.409501

[77] Treynor, J.L. (1965) How to Rate Management of Investment Funds. Harvard Business Review, 43, 63-75.

[78] Camanho da Costa Neto, N. and Romeu, R. (2011) Did Export Diversification Soften the Impact of the Global Financial Crisis? IMF Working Paper, No. 11/99, IMF, Washington DC.

https://www.imf.org/external/pubs/ft/wp/2011/wp1199.pdf 
Scientific Research Publishing (SCIRP) is one of the largest Open Access journal publishers. It is currently publishing more than 200 open access, online, peer-reviewed journals covering a wide range of academic disciplines. SCIRP serves the worldwide academic communities and contributes to the progress and application of science with its publication.

Other selected journals from SCIRP are listed as below. Submit your manuscript to us via either submit@scirp.org or Online Submission Portal.
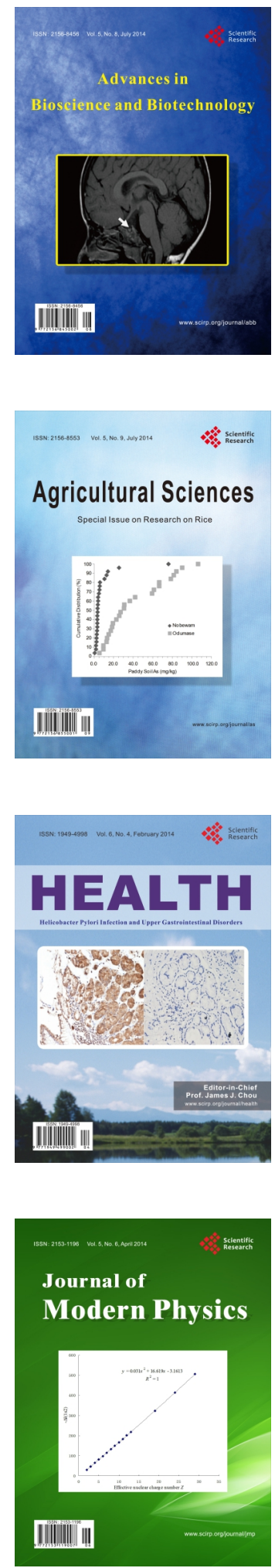
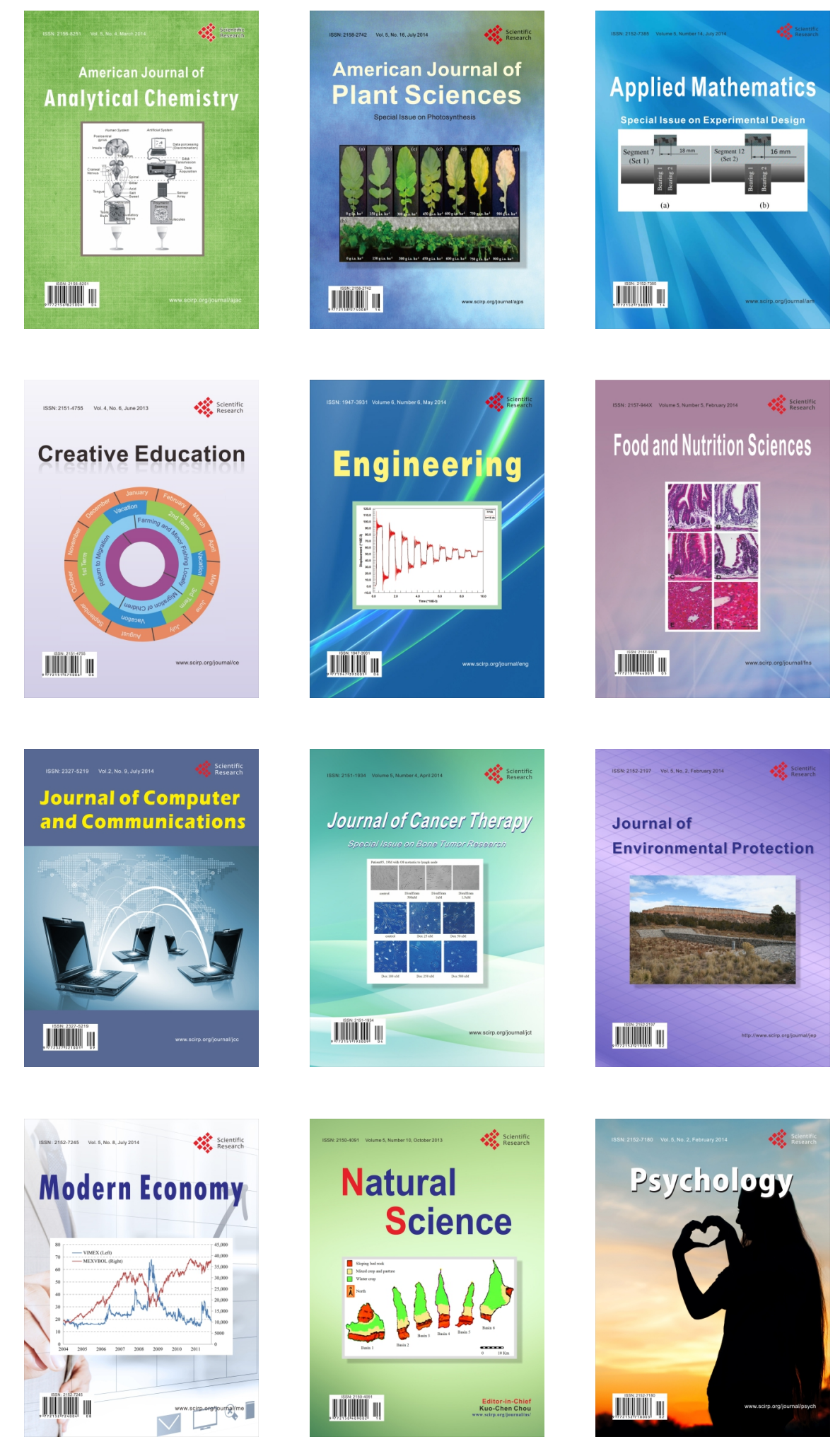